OPEN ACCESS

Edited by:

Andrew C. Mitchell, Aberystwyth University,

United Kingdom

Reviewed by:

Gilad Antler,

Ben-Gurion University of the Negev,

Israel

Ziming Yang,

Oakland University, United States

${ }^{*}$ Correspondence: Jon Hawkings

jon.hawkings@gmail.com

Specialty section: This article was submitted to

Geochemistry,

a section of the journal

Frontiers in Earth Science

Received: 18 July 2018 Accepted: 21 November 2018 Published: 11 December 2018

Citation:

Raiswell R, Hawkings J, Elsenousy A, Death $R$, Tranter $M$ and Wadham (2018) Iron in Glacial Systems: Speciation, Reactivity, Freezing Behavior, and Alteration During

Transport. Front. Earth Sci. 6:222. doi: 10.3389/feart.2018.00222

\section{Iron in Glacial Systems: Speciation, Reactivity, Freezing Behavior, and Alteration During Transport}

\author{
Robert Raiswell ${ }^{1}$, Jon Hawkings ${ }^{2,3,4 *}$, Amira Elsenousy ${ }^{5}$, Ros Death $^{2}$, Martyn $^{\text {Tranter }}{ }^{2}$ and \\ Jemma Wadham ${ }^{2}$ \\ ${ }^{1}$ Cohen Biogeochemistry Laboratories, School of Earth and Environment, Leeds University, Leeds, United Kingdom, ${ }^{2}$ Bristol \\ Glaciology Centre, School of Geographical Sciences, Bristol University, Bristol, United Kingdom, ${ }^{3}$ National High Magnetic \\ Field Lab and Earth, Ocean and Atmospheric Sciences, Florida State Universtiy, Tallahassee, FL, United States, ${ }^{4}$ German \\ Research Centre for Geosciences GFZ, Potsdam, Germany, ${ }^{5}$ Department of Earth Sciences, University of California, \\ Riverside, Riverside, CA, United States
}

A more insightful view of iron in glacial systems requires consideration of iron speciation and mineralogy, the potential for iron minerals to undergo weathering in ice-water environments, the impact of freezing on concentration and speciation, and potential for glacial delivery to undergo alteration during transport into the ocean. A size fractionation approach improves recognition of iron speciation by separating dissolved $\mathrm{Fe}(<0.2$ or $<0.45 \mu \mathrm{m})$ into soluble Fe $(<0.02 \mu \mathrm{m})$ and colloidal/nanoparticulate Fe (0.02 to 0.2 or $0.45 \mu \mathrm{m})$. The ranges of soluble Fe concentrations in icebergs and meltwaters are similar (tens of nanomolar). The range of colloidal/nanoparticulate Fe concentrations in icebergs are an order of magnitude higher (hundreds of nanomolar) and up to thousands of nanomolar in meltwaters. The importance of particulate iron speciation in glacial sediments is also recognized by using carefully calibrated sequential extractions with ascorbic acid (FeA comprising fresh ferrihydrite which is potentially bioavailable) and dithionite (FeD comprising all remaining (oxyhydr)oxide Fe). Iceberg and glacier sediments contain lower concentrations of FeA $(0.032 \pm 0.024$ and $0.042 \pm 0.059$ wt. \%) than meltwater suspended sediments (FeA $0.12 \pm 0.09$ wt. \%). Glacier sediments also contain low concentrations of FeD $(0.060 \pm 0.036)$ but concentrations of FeD are comparable in iceberg and meltwater sediments (0.38 \pm 0.24 wt. \% compared to $0.31 \pm 0.09$ wt.\%). Reactions in ice-water systems produce potentially bioavailable Fe(II) and ferrihydrite by pyrite oxidation, iron mineral dissolution (aided by low $\mathrm{pH}$ and organic complexes) and reduction (aided by UV radiation). Some icebergs contain high concentrations of FeA (>0.1 wt. \%) which represent samples in which the on-going transformation of ferrihydrite to goethite/hematite is incomplete. Numerical models of freezing in subglacial systems show that the nanomolar levels of soluble Fe in icebergs cannot be achieved solely by freezing, and must indicate the presence of nanoparticulate $\mathrm{Fe}$ and/or iron desorbed from ice or sediments during melting. Models of freezing effects in sea ice show that nanomolar levels of soluble Fe are achievable because high concentrations of hydroxide and chloride ions maintain dissolved iron as soluble complexes. Delivery of iron through fjords is temporally and spatially variable due to circulation patterns, mixing of different sources, and aggregation through salinity gradients.

Keywords: iron, speciation, icebergs, meltwaters, freezing 


\section{INTRODUCTION}

Recent studies of the iron cycle in the Southern Ocean acknowledge a range of sources, although the primary focus remains on iron sourced from atmospheric dust, continental shelf sediments and hydrothermal inputs (Tagliabue et al., 2016). Many publications also show the Antarctic Ice Sheet is a potential iron source, both to the open ocean and the shelf. Thus studies of iceberg Fe delivery to the Southern Ocean by Smith et al. (2007, 2013); Raiswell et al. (2008, 2016); Shaw et al. (2011); Death et al. (2014); Duprat et al. (2016) and Herraiz-Borreguero et al. (2016) are supported by many others showing dissolved and particulate Fe delivery from a variety of different localized glacial sources (Lannuzel et al., 2008, 2014; Gerringa et al., 2012; De Jong et al., 2013, 2015; Annett et al., 2015, 2017; Lyons et al., 2015; Monien et al., 2017). These publications demonstrate a significant role for glacial processes in delivering potentially bioavailable Fe to the Southern Ocean.

Here we will construct five working hypotheses in relation to iron behavior in glacial systems and examine the status of each in the light of new and/or recent developments. We contend that; (1) A more detailed approach to iron speciation and mineralogy will improve our understanding of iron behavior and potential bioavailability, (2) Iron minerals stored in ice can undergo a variety of reactions that may enhance or diminish potential bioavailability, (3) Freezing iron-subglacial water systems may concentrate potentially bioavailable species, (4) Freezing iron-seawater systems may concentrate potentially bioavailable species, (5) The delivery of dissolved iron may undergo significant alteration during post-melt transport. Our examples mainly focus on the Arctic but these approaches should also be applied to the Southern Ocean iron cycle. However, we exclude any detailed discussion of the influence glacial sources might have on productivity, as there are no areas in the Arctic Ocean which are currently known to be persistently iron-limited.

A primary goal of research in the iron cycle is to identify and measure those species of iron that are capable of enhancing productivity when delivered to High Nutrient-Low Chlorophyll waters. However, different organisms have widely varying abilities to transform different $\mathrm{Fe}$ species into a form that can be assimilated (Shaked and Lis, 2012). Furthermore bioavailability can be influenced by a wide variety of factors external to the organism (e.g., ligand concentrations, photochemistry, biological reduction, and enzymatic reduction at the cell surface). Hence there is no simple definition of bioavailability. Aqueous $(<0.02 \mu \mathrm{m})$ inorganic and organically-bound iron are considered the most bioavailable species (Shaked and Lis, 2012; Tagliabue et al., 2017). Fe(II) is regarded as being more readily bioavailable (von der Heyden et al., 2012; Shoenfelt et al., 2017) than $\mathrm{Fe}(\mathrm{III})$, which is poorly soluble in seawater. Fresh amorphous iron (III) (oxyhydr)oxides are also considered a better source of bioavailable $\mathrm{Fe}$ than aged or more crystalline minerals (e.g., Yoshida et al., 2006). Clearly iron measurements in biogeochemical studies should to be related to those species that are potentially bioavailable, including aqueous $\mathrm{Fe}$, and fresh amorphous iron (oxyhydr)oxides.

\section{DETAILED APPROACHES TO IRON SPECIATION AND MINERALOGY}

\section{Background}

Wells and Goldberg (1994) have observed that "distinguishing between soluble, colloidal and particulate phases will be essential if we are to understand the cycling of matter in the ocean." Here we evaluate current practice in this context, identify improved approaches to determine speciation and mineralogy, and evaluate results obtained using these approaches.

\section{Dissolved Iron}

Measurements of dissolved $\mathrm{Fe}(\mathrm{dFe})$ are routinely made by filtration through 0.45 or $0.2 \mu \mathrm{m}$ filters and thus these measurements are based on size, not speciation. Size fractions only crudely approximate to speciation; the fraction $>1.0 \mu \mathrm{m}$ is particulate, that between 0.1 and $1.0 \mu \mathrm{m}$ is colloidal and that between 0.02 and $0.1 \mu \mathrm{m}$ is nanoparticulate. Only the $<0.02 \mu \mathrm{m}$ fraction contains any significant concentration of aqueous species.

We will use the following convention (Table 1) based on Hawkings et al. (2014) and Von der Heyden and Roychoudhury (2015), as described below.

a) Aqueous $\mathrm{Fe}(\mathrm{aqFe})$ comprises all truly aqueous $\mathrm{Fe}$, including the ionic species $\mathrm{Fe}^{3+}$ and $\mathrm{Fe}^{2+}$ and all their complexes with inorganic and organic ligands,

b) Soluble $\mathrm{Fe}(\mathrm{sFe})$ includes all aqFe plus those nanoparticles that pass through a $0.02 \mu \mathrm{m}$ filter,

c) Colloidal/nanoparticulate $\mathrm{Fe}(\mathrm{CNFe})$ includes all $\mathrm{Fe}$ between 0.02 and 0.2 or $0.45 \mu \mathrm{m}$,

d) Dissolved $\mathrm{Fe}(\mathrm{dFe})=\mathrm{sFe}+\mathrm{CNFe}$,

e) Particulate $\mathrm{Fe}(\mathrm{pFe})$ is all $\mathrm{Fe}$ extracted from material $>0.2$ or $0.45 \mu \mathrm{m}$.

The sFe fraction comprises $\sim 30-40 \%$ of $\mathrm{dFe}$ in the open ocean whereas the colloidal/nanoparticulate/ fraction comprises at least 60-70\% (Boye et al., 2010; Von der Heyden and Roychoudhury, 2015). Few measurements of sFe have been made in glacial systems although $\mathrm{sFe}$ is probably the best empirical measure of potentially bioavailable aqueous iron.

It is important to recognize that the CNFe fraction includes solid and amorphous phases and comprises complex mixtures of organic and inorganic materials. The inorganic materials are minerals (or mineral aggregates) whose properties are modified by size and by the nature of the organic admixtures and/or complexes. There are a variety of techniques (Shi et al., 2012; Raiswell et al., 2017) available to study the CNFe fraction. These techniques include; scanning electron microscopy (SEM), high resolution transmission electron microscopy (HRTEM), energy dispersive X-ray spectrometry (EDX) and selective area X-ray diffraction (SAED), all of which provide compositional, structural, and mineralogical information down to nanometre scales. Synchroton-based spectroscopy data (e.g., $\mathrm{X}$-ray absorption near-edge structure or XANES) can also be used to identify Fe valency at high resolution. The above techniques have been used on glacial sediments to determine mineralogy and Fe valency, most recently by von der Heyden et al., 2012, 
TABLE 1 | Explanation of the terminology used.

\begin{tabular}{|c|c|}
\hline Terminology & Meaning \\
\hline aqFe & $\begin{array}{l}\text { All truly aqueous species including } \mathrm{Fe}^{2+} \text { and } \mathrm{Fe}^{3+} \text { and their } \\
\text { organic and inorganic complexes. }\end{array}$ \\
\hline $\mathrm{sFe}$ & $\begin{array}{l}\text { Soluble Fe measured after filtration through } 0.02 \mu \mathrm{m} \text {. All aqFe plu } \\
\text { nanoparticles that pass through } 0.02 \mu \mathrm{m} \text {. }\end{array}$ \\
\hline CNFe & Colloidal/Nanoparticulate Fe. All Fe from 0.02 to 0.2 or $0.45 \mu \mathrm{m}$. \\
\hline $\mathrm{dFe}$ & $\begin{array}{l}\text { Dissolved Fe (DFe in some literature). All Fe that passes through } \\
0.2 \text { or } 0.45 \mu \mathrm{m} . \mathrm{dFe}=\mathrm{sFe}+\mathrm{CNFe} \text {. }\end{array}$ \\
\hline $\mathrm{pFe}$ & Particulate Fe. All Fe > 0.2 or $0.45 \mu \mathrm{m}$ \\
\hline FeA & $\begin{array}{l}\text { Fe measured using an ascorbic acid extraction. Mainly fresh } \\
\text { ferrihydrite. }\end{array}$ \\
\hline FeD & $\begin{array}{l}\text { Fe measured using a dithionite extraction after removal of FeA. } \\
\text { Mainly goethite and hematite. }\end{array}$ \\
\hline TDFe & Fe solubilised at $\mathrm{pH} 2$ without prior filtration. \\
\hline OBS & $\begin{array}{l}\text { Optical Back Scattering. A measure of particle concentrations or } \\
\text { turbidity. }\end{array}$ \\
\hline
\end{tabular}

Hawkings et al. (2014, 2018) and Shoenfelt et al. (2017, 2018). Their valuable insights are discussed below.

\section{Particulate Fe}

The particulate fraction is commonly defined in terms of fractional solubility which is the percentage of total Fe that passes through a $0.2,0.4$, or $0.45 \mu \mathrm{m}$ filter after treatment with a specified extractant (Meskhidze et al., 2016; Raiswell et al., 2017). Unfortunately a wide variety of extraction techniques are commonly used such that fractional solubilities vary widely, e.g., the fractional solubility of aeolian dusts ranges from 0.001 to 80\% (Jickells and Spokes, 2001; Baker and Croot, 2010). Many modeling studies simply use a solubility value of $1-2 \%$ for aeolian dusts although the extraction data of Jickells and Spokes, 2001 indicate that this choice is arbitrary (Boyd et al., 2010). However this choice is supported ascorbic acid extractions of iron from aeolian dusts, which correspond to a fractional solubility of $\sim 1 \%$ (see paragraph below and Raiswell et al., 2016).

Many extraction methodologies provide only qualitative statements on mineral extraction behavior and few of these distinguish between the different $\mathrm{Fe}$ (oxyhydr)oxides (ferrihydrite, lepidocrocite, goethite, and hematite) although the optimum target is ferrihydrite. Baker et al. (2006) use a pH 4.7 acetate extraction which Poulton and Canfield (2005) found to dissolve carbonate $\mathrm{Fe}$ but only negligible concentrations of ferrihydrite, lepidocrocite, goethite, and hematite. It is likely that this extraction also dissolves weakly-bound $\mathrm{Fe}$ (e.g., adsorbed or surface active) non-carbonate Fe. Chen et al. (2003) use a $\mathrm{pH} 4.5$ formate-acetate extraction which was stated to dissolve Fe (oxyhydr)oxides (mineralogy unspecified). Winton et al. (2015) report that $\mathrm{pH} 2$ hydroxylamine hydrochloride dissolves Fe from biogenic material, Fe adsorbed to clay minerals and $\mathrm{Fe}$ as (oxyhydr)oxides (but only from ferrihydrite and lepidocrocite; see Poulton and Canfield, 2005). The distilled water leach technique of Buck et al. $(2006,2010)$ is believed to extract Fe-rich nanoparticles, $\mathrm{Fe}$ (oxyhydr)oxides and $\mathrm{Fe}$ in aluminosilicate minerals. Raiswell et al. (2010) use a pH
TABLE 2 | Means and ranges of sFe and CNFe in icebergs and meltwaters (nM).

\begin{tabular}{lccccc}
\hline & $\begin{array}{c}\text { Range } \\
\text { sFe }\end{array}$ & $\begin{array}{c}\text { Mean } \\
\text { sFe }\end{array}$ & $\begin{array}{c}\text { Range } \\
\text { CNFe }\end{array}$ & $\begin{array}{c}\text { Mean } \\
\text { CNFe }\end{array}$ & $\begin{array}{c}\text { Range dFe }= \\
\text { sFe + CNFe }\end{array}$ \\
\hline lcebergs & $<1-20$ & $5.7 \pm 6.6$ & $<1-550$ & $104 \pm 160$ & $1-550$ \\
Meltwaters & $<1-60$ & $10 \pm 10$ & $200-9000$ & $570 \pm 520$ & $200-9000$ \\
\hline
\end{tabular}

7.5 ascorbic acid extraction that is highly selective for fresh ferrihydrite and which dissolves only very small concentrations of iron from aged ferrihydrite, lepidocrocite, goethite, hematite, and aluminosilicate minerals. Following the extraction of FeA, the residual, more crystalline iron (oxyhydr)oxides can be removed by a dithionite extraction as $\mathrm{FeD}$ (Raiswell et al., 1994). The significance of ferrihydrite is that the pure, freshly precipitated mineral phase (commonly termed HFO or Hydrous Ferric Oxide) has been found experimentally to be bioavailable (Wells et al., 1983; Rich and Morel, 1990; Kuma and Matsunaga, 1995; Nodwell and Price, 2001). Hence the quantitative extraction of fresh ferrihydrite by ascorbic acid represents a rough measure of potentially bioavailable particulate $\mathrm{Fe}$.

\section{New Insights Dissolved Iron}

Here we present speciation data for dissolved iron in icebergs and meltwaters. Iceberg sFe and CNFe data are available only for icebergs sampled from Greenland and Svalbard from Hawkings (2015). Icebergs from Greenland (7 samples) have range of sFe from below detection limit to $11 \mathrm{nM}$ and CNFe from 7 to $182 \mathrm{nM}$. In Svalbard icebergs (8 samples) the sFe ranges from below detection limit to $20 \mathrm{nM}$ and $\mathrm{CNFe}$ ranges from below detection limit to $550 \mathrm{nM}$. These two data set provide a mean for sFe of $5.7 \pm 6.6 \mathrm{nM}$ and for CNFe of $104 \pm 160 \mathrm{nM}$. Data for CNFe only are available from Hopwood et al. (2016) who measure concentrations of 3-300 nM in Greenlandic icebergs, Table 2 presents an estimated range of $<1$ to $20 \mathrm{nM}$ for sFe and $<1$ to $550 \mathrm{nM}$ for CNFe.

Table 2 shows data for glacial meltwaters draining from the Greenland Ice Sheet for which there are measurements of sFe and CNFe. Hawkings et al. (2014) published analytical data for more than 60 samples of meltwater from the Leverett Glacier that show sFe ranging $<1$ to $37 \mathrm{nM}$. Rather higher sFe data have been found by Statham et al. (2008) for the Bristol Glacier (range 6 to $51 \mathrm{nM}$ ) and the Bath Glacier (range 10 to $60 \mathrm{nM}$ ) and together these two data sets suggest a range of $\mathrm{sFe}$ from $<1$ to $60 \mathrm{nM}$ with a mean of $10 \pm 10 \mathrm{nM}$ (Table 2). Hawkings et al. (2014) found CNFe ranging from 230 to $4,700 \mathrm{nM}$ for the Leverett meltwaters but Statham et al. (2008) found much lower CNFe measurements (Bristol Glacier 2 to $86 \mathrm{nM}$; Bath Glacier 10 to $117 \mathrm{nM}$ ). Together these data suggest a range of CNFe of $2-4700 \mathrm{nM}$ and a mean of $570 \pm 520 \mathrm{nM}$. This range is rather lower than the range of $\mathrm{dFe}$ (essentially equivalent to CNFe, see above) found by Bhatia et al. (2013) for runoff sampled close to three Greenlandic glaciers (range 2200 to $9300 \mathrm{nM}$ ). However the data are few and are here used uncritically in Table 2 which estimates the range for CNFe in meltwaters as 200 to $9000 \mathrm{nM}$. 


\section{Particulate Fe Mineralogy}

von der Heyden et al. (2012) studied the $>0.2 \mu \mathrm{m}$ fraction of particles collected from the Southern Ocean which mainly comprised discrete $20-700 \mathrm{~nm}$ nanoparticulate aggregates. XANES spectra of glacially-influenced samples from the Weddell Sea gyre contained Fe(II)-rich nanoparticles closely associated with organic C. In the Southern Ocean beyond the Weddell Sea $\mathrm{Fe}$ (III)-rich particles were found with X-ray spectral features more characteristic of $\mathrm{Fe}$ (III) (oxyhydr)oxides. Glacial and iceberg sediments have also been shown to contain $\mathrm{Fe}(\mathrm{II})$ in ferrihydrite-like phases (Hawkings et al., 2018). XANES spectra were used to study amorphous $\mathrm{Fe}$ nanophases (previously identified as ferrihydrite by Hawkings et al., 2014) in iceberg and meltwater suspended sediment particulates. The iceberg particles comprised mixtures of $\mathrm{Fe}$ (III) and $\mathrm{Fe}$ (II) containing up to $\sim 40 \% \mathrm{Fe}(\mathrm{II})$. Shoenfelt et al. (2017) used X-ray absorption spectroscopy to show that glacial sediments contained Fe(II)bearing minerals (with spectra corresponding to silicates) were more bioavailable than non-glacial sediments containing mainly $\mathrm{Fe}$ (III) silicates and (oxyhydr)oxides. These studies suggest that determining the $\mathrm{Fe}$ (II) content of CNFe should be an important research target, with the presence of $\mathrm{Fe}$ (II) in ferrihydrite and/or silicate minerals representing a powerful argument for the bioavailability of iceberg sediments and meltwater suspended sediments.

Hitherto fresh ferrihydrite has been regarded as the most likely mineral source of bioavailable $\mathrm{Fe}$ (see above). However, Shoenfelt et al. $(2017,2018)$ show that Fe(II) derived from aluminosilicates (thought to be surface-active and weakly-bound in glacial sediments) is also bioavailable. This surface Fe(II) will be dissolved by ascorbic acid because the mechanism of ascorbic acid dissolution (Banwart et al., 1989) is initiated by the reduction of $\mathrm{Fe}$ (III), with surface (Fe(II) then being more readily detached than the residual mineral Fe(III). Hence FeA will comprise both Fe reduced from fresh $\mathrm{Fe}$ (III) as well any mineral surface Fe(II). Concentrations of FeA extracted from Fe(II)-bearing silicates range from 0.03 to 0.05 wt. \% (Raiswell et al., 2010) which are capable of producing $\sim 100 \mathrm{nM}$ concentrations of Fe where iron silicate loadings are $\sim 10 \mathrm{mg} /$ liter (which represents $10 \%$ of a sediment load of $0.1 \mathrm{~g} /$ liter). These concentrations of FeA derived from $\mathrm{Fe}$ silicates are comparable to the range of $\mathrm{sFe}$ concentrations in icebergs and meltwaters $(<1-60 \mathrm{nM}$; Table 2). Trace amounts of $\mathrm{Fe}(\mathrm{II})$, whatever their mineralogy, in glacial sediments can clearly be a source of bioavailable Fe. The ascorbic acid extraction is therefore able to provide the best estimate of potential bioavailable $\mathrm{Fe}$ from both aluminosilicates or fresh ferrihydrite.

\section{Particulate Fe Speciation}

Data for iron present as ferrihydrite (FeA) in sediment-laden ice from glaciers are currently available from Raiswell et al. (2016) and Hopwood et al. (2017). Here we derive a combined glacial data base (Table 3 ) using the 8 samples collected from the Russell and Mittivakkt Glaciers (Greenland), Finsterwalderbreen (Svalbard), and Engabreen (Norway), as described by Raiswell et al. (2016). These data are combined with 12 samples (those embedded in ice) from the Midtre Lovenbreen and Kongsvegen Glaciers (Greenland) from Hopwood et al. (2017). Surface glacial samples are excluded due to their potential for alteration during sub-aerial exposure. The small 8 sample data set from Raiswell et al. (2016) deviated from normality and were treated as log normal but this data set, when combined with the Hopwood et al. (2017) data, more closely approaches normality and arithmetic means and standard deviations can be used with caution, as is the case for subsequent data compilations. These data (from 6 different glaciers) have mean of $0.042 \pm 0.059$ wt. \%.

The iceberg sediment FeA content is recorded in Table 3. There are two sets of Arctic iceberg data. One set utilizes 30 iceberg samples from Greenland (Sermilik and Tunulliarfik fjords) and Svalbard (Kongsfjorden, Liefdenfjorden, and Wallensbergfjorden) from Raiswell et al. (2016) but excludes samples with $>0.1$ wt. \% FeA (as discussed in Particulate iron speciation controls). The other data set uses 34 samples (those embedded in ice) from icebergs in Kongsfjorden (Svalbard; Hopwood et al., 2017). These two iceberg data sets have different mean FeA contents $(0.047 \pm 0.020$ and $0.019 \pm 0.020$ wt. $\%)$ due sampling methodology and sample heterogeneity as well as differences in bedrock geology (see Hopwood et al., 2017). However there is overlap in the two means and standard deviations and combining the two data sets produces a mean of $0.032 \pm 0.024$ wt. \% FeA and $0.38 \pm 0.24$ wt \% FeD.

The Greenlandic meltwater sediment compositions in Table 3 (Hawkings, 2015) are based on analyses of 33 samples taken from Leverett Glacier in 2012, 28 samples taken from Kiattuut Sermiat in 2013 and a further 16 samples taken from Leverett Glacier in 2015. Meltwater suspended sediment concentrations are variable seasonally and spatially (between localities). The samples taken from Leverett Glacier in years 2012 and 2015 are not significantly different (FeA $0.15 \pm 0.02$ wt. $\%$ and $0.13 \pm 0.07$ wt.\%; FeD $0.38 \pm 0.08$ wt. $\%$ and $0.31 \pm 0.07$ wt. $\%)$ but the samples from Kiattuut Sermiat have significantly lower concentrations of FeA $(0.074 \pm 0.018$ wt.\%) and FeD $(0.22 \pm 0.05$ wt.\%). These data provide a mean FeA content of $0.12 \pm 0.09$ and mean FeD content of $0.31 \pm 0.09$ wt. \%. A discharge-weighted mean would provide slightly higher mean values for $\mathrm{FeA}$ and $\mathrm{FeD}$ as the annual discharge at Kiattuut Sermiat is an order of magnitude lower than that at Leverett Glacier (Hawkings et al., 2016). Interestingly the ratios of $\mathrm{FeA} / \mathrm{FeD}$ are not significantly different between the three sample sets (Leverett 2012 is $0.39 \pm 0.08$; Kiatuut 2013 is $0.34 \pm 0.11$ and Leverett 2015 is $0.43 \pm 0.25$ ) and the mean $\mathrm{FeA} / \mathrm{FeD}$ ratio is $0.39 \pm 0.20$.

\section{Synthesis}

Some preliminary conclusions can be drawn from Tables 2, 3 but these require further validation as the data sets are small and representivity is low.

(i) The ranges of iceberg and meltwater sFe are comparable but values are considerably in excess of the saturation levels with respect to iron (oxyhydr)oxides (see Synthesis in following section). A variety of factors may be responsible; kinetic effects may inhibit the precipitation of iron (oxyhydr)oxides, sFe may contain large concentrations of nanoparticles $<0.02 \mu \mathrm{m}$, organic complexes may stabilize aqFe in solution (see Complexing and adsorption) and $s F e$ 
TABLE 3 | Means and standard deviations of FeA and FeD in sediments from glaciers, icebergs and meltwaters.

\begin{tabular}{lcccc}
\hline & FeA wt. \% & FeD wt. \% & FeA/FeD & No Samples \\
\hline Glaciers & $0.042 \pm 0.059$ & $0.060 \pm 0.036$ & $0.48 \pm 0.07$ & 20 \\
lcebergs & $0.032 \pm 0.024$ & $0.38 \pm 0.24$ & $0.08 \pm 0.08$ & 64 \\
Meltwaters & $0.12 \pm 0.09$ & $0.31 \pm 0.09$ & $0.39 \pm 0.20$ & 77 \\
\hline
\end{tabular}

may have been de-sorbed from ice or sediment surfaces during melting.

(ii) Icebergs contain an order magnitude more CNFe than $\mathrm{sFe}$, but concentrations are comparable with $\mathrm{CNFe}(=\mathrm{dFe})$ in mean river water (740 nM; De Baar and de Jong, 2001). Meltwaters sampled near the glacier portal may have higher $\mathrm{CNFe}$ concentrations than rivers due to turbulence and insufficient time for aggregation and settling. Potentially bioavailable $\mathrm{Fe}$ found in $\mathrm{CNFe}$ includes ferrihydrite and surface-active Fe in silicates.

(iii) Mean concentrations of potentially bioavailable FeA (representing fresh ferrihydrite and surface extracted $\mathrm{Fe}$ ) are comparable in glaciers $(0.042$ wt. \%), icebergs $(0.032$ wt. \%) but much higher in meltwater suspended sediments (0.12 wt. \%).

\section{IRON MINERAL REACTIONS IN ICE-WATER SYSTEMS}

\section{Background}

A variety of complex reactions may occur in ice-hosted, sediment-bearing layers or cavities, the inter-play between which depends primarily on sediment and water composition. These reactions have the potential to greatly enhance the $\mathrm{Fe}$ content of ice (as $\mathrm{sFe}, \mathrm{CNFe}$ and $\mathrm{pFe}$ ). The following discussion uses a solubility product of ferrihydrite, $\left(\mathrm{K}_{\mathrm{sp}} \sim 10^{-39} \mathrm{~mol}^{-4} \mathrm{l}^{-4}\right.$; Stumm and Morgan, 1981) here defined qualitatively in concentration terms (i.e. for an ideal solution) as;

$$
\begin{aligned}
& \mathrm{Fe}(\mathrm{OH})_{3} \rightarrow \mathrm{Fe}^{3+}+3 \mathrm{OH}^{-} \\
& \mathrm{K}_{\mathrm{sp}}=\left(\mathrm{Fe}^{3+}\right)\left(\mathrm{OH}^{-}\right)^{3}=\sim 10^{-39} \mathrm{~mol}^{-4} \mathrm{l}^{-4}
\end{aligned}
$$

Solutions with ion product levels that exceed $\mathrm{K}_{\mathrm{sp}}$ are saturated with ferrihydrite and further dissolution cannot occur. However, the $\mathrm{K}_{\mathrm{sp}}$ is defined in terms of the $\mathrm{Fe}^{3+}$ ion only, and thus complexes with the $\mathrm{Fe}^{3+}$ ion do not contribute to saturation levels (see Complexing and adsorption).

\section{Oxidation of Pyrite and Fe(II) Silicates}

Sediments may remain encased in ice for periods of time that range from a few years for sea ice, up to thousands of years for subglacial ice. However, the kinetics of most mineral reactions are slow at freezing temperatures, and only rapid reactions are likely to be significant, particularly on the shorter timescales. In oxic microenvironments the most rapid iron mineral reactions involve the oxidation of pyrite and/or other Fe(II) minerals (Tranter et al., 2002; Wadham et al., 2010). The identification of schwertmannite in iceberg sediments specifically implicates pyrite oxidation
(Raiswell et al., 2009) which produces iron (oxyhydr)oxides (written here as $\mathrm{Fe}(\mathrm{OH})_{3}$ ) and acidic species (Nordstrom, 2011);

$$
\mathrm{FeS}_{2}+15 / 4 \mathrm{O}_{2}+7 / 2 \mathrm{H}_{2} \mathrm{O} \rightarrow \mathrm{Fe}(\mathrm{OH})_{3}+2 \mathrm{SO}_{4}^{2-}+4 \mathrm{H}^{+}
$$

Iron oxidizing bacteria are important in catalyzing this reaction and the resulting $\mathrm{Fe}^{3+}$, formed from the dissociation of $\mathrm{Fe}(\mathrm{OH})_{3}$ in acidic conditions, oxidizes pyrite more rapidly than oxygen (Moses et al., 1987). Thus reaction (2) can be written as;

$$
\mathrm{FeS}_{2}+14 \mathrm{Fe}^{3+}+8 \mathrm{H}_{2} \mathrm{O} \rightarrow 15 \mathrm{Fe}^{2+}+2 \mathrm{SO}_{4}^{2-}+16 \mathrm{H}^{+}
$$

and the resulting acidity produces proton-assisted dissolution (see Dissolution and reduction of Fe(III) oxides) unless buffered by carbonate minerals. Pyrite oxidation proceeds very rapidly because the oxidation of $\mathrm{Fe}^{2+}$ to $\mathrm{Fe}^{3+}$ is biologically mediated by iron oxidizing bacteria whereas the abiotic reaction of $\mathrm{Fe}^{2+}$ with dissolved oxygen is slower. Nordstrom (1982) concluded that oxidation via $\mathrm{Fe}^{3+}$ (with a half -life $\sim 1.5$ to 15 days) predominates at $\mathrm{pH}<8$. Above $\mathrm{pH} 8, \mathrm{Fe}^{3+}$ hydrolyses, and precipitates as $\mathrm{Fe}(\mathrm{OH})_{3}$ and oxygen becomes the most important oxidant (and the half -life for oxidation increases to about a year). Both biotic and biotic oxidation have been observed down to $-12^{\circ} \mathrm{C}$ (Elberling, 2005).

Similarly rapid oxidation rates are found in seawater. Gartman and Luther (2014) have conducted experiments in oxygenated seawater at $\mathrm{pH} 8$ and $25^{\circ} \mathrm{C}$ using synthesized pyrite (faster rates are found using crushed mineral pyrite). These experiments found half-lives for initial rates of oxidation ranging from 13 to 356 days, depending on the initial concentrations of the reactants, but not on particle size or surface area. Rates were found to be $\sim 3 \mathrm{x}$ faster in diluted (half strength) seawater but $\sim 3 \mathrm{x}$ slower at $9^{\circ} \mathrm{C}$. These data suggest that oxidation rates will be slower in sea ice (where temperatures are typically sub-zero and solutes are concentrated by freezing).

The oxidation of Fe(II) in silicates or carbonates occurs less rapidly because insufficient acidity is generated to solubilise the $\mathrm{Fe}^{3+}$ needed to catalyze rapid microbial oxidation. These reactions also produce iron (oxyhydr)oxides but are only likely to be more important in older ice.

$$
\mathrm{Fe}_{2} \mathrm{SiO}_{4}+1 / 2 \mathrm{O}_{2}+5 \mathrm{H}_{2} \mathrm{O} \rightarrow 2 \mathrm{Fe}(\mathrm{OH})_{3}+\mathrm{H}_{4} \mathrm{SiO}_{4}
$$

Reactions 2 to 4 all consume oxygen and may thus produce dysoxic or anoxic microenvironments in which pyrite can be oxidized using nitrate (e.g., Bosch et al., 2012). In summary, the rapid weathering of $\mathrm{Fe}(\mathrm{II})$-bearing minerals in oxic conditions produces a high degree of supersaturation that favors the formation of nanoparticles of ferrihydrite (Waychunas et al., 2005).

\section{Dissolution and Reduction of $\mathrm{Fe}$ (III) Oxides}

Dissolution of ferrihydrite (and other iron (oxyhydr)oxides) can occur in aqueous, ice-enclosed cavities and produces $\mathrm{Fe}^{3+}$ as in equation (1). The slightly acidic $\mathrm{pH}$ (5.5-6.0) of snow and glacial ice melt (see New Insights in following section and Tranter and Jones, 2001) expedites proton-assisted 
dissolution of iron minerals. Dissolution in glacial and sea ice is also enhanced because freezing concentrates particulate iron and protons into liquid at ice grain boundaries (Kim et al., 2010). In a closed system the accumulation of aqueous $\mathrm{Fe}^{3+}$ rapidly produces saturation with respect to ferrihydrite and dissolution stops when the solubility product $\left(\sim 10^{-39}\right)$ is reached, unless the $\mathrm{pH}$ becomes more acidic (consuming $\mathrm{OH}^{-}$) and/or unless complexing and adsorption occur (which decrease the concentration of $\mathrm{Fe}^{3+}$ ).

Reducing environments can result where closed system pyrite oxidation is able to consume the available oxygen. Iron (oxyhydr)oxides may then be microbially reduced in anaerobic subglacial environments that are able to host viable iron reducing bacteria (Nixon et al., 2017). $\mathrm{Fe}^{3+}$ can also be abiotically reduced to ferrous iron in near-surface ice by UV (shown as $h v$ ) radiation (Kim et al., 2010).

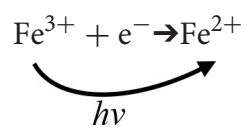

UV radiation can penetrate to depths of $5-10 \mathrm{~cm}$ into ice depending on ice crystallinity, sediment content etc. (Rowland and Grammas, 2011). The resulting ferrous iron may be incorporated into ice during freeze/thaw cycles (see Freeze-thaw reactions in ice) although ferrous iron at shallow depths in ice will be rapidly re-oxidized to (oxyhydr)oxide minerals where ice becomes permeable or melts.

\section{Complexing and Adsorption}

Complexing plays an important role by removing the $\mathrm{Fe}^{3+}$ formed in equation (1) into species that do not influence the solubility product. However, complexed species still contribute to aqFe and sFe. The most abundant inorganic species that have the ability to complex $\mathrm{Fe}^{3+}$ are the hydroxide and chloride ions (see Geochemical modeling sections). Organic complexes (Lannuzel et al., 2014) are important in sea ice and the presence of EPS (extracellular polymeric substances) both aids dissolution and converts $\mathrm{Fe}^{3+}$ into a complex which has no influence on the solubility product.

$$
\mathrm{Fe}(\mathrm{OH})_{3}+\mathrm{EPS} \rightarrow \mathrm{Fe}^{3+}(\mathrm{EPS} \text { complex })+3 \mathrm{OH}^{-}
$$

Adsorption of multi-valent ions may also occur to ice surfaces (Lannuzel et al., 2014) and to negatively charged species such as clay minerals. The removal of $\mathrm{Fe}^{3+}$ by adsorption thus diminishes the contribution of this ion to the solubility product but the adsorped species may still be measured as $\mathrm{sFe}$ and $\mathrm{CNFe}$ (when released from melted ice) or $\mathrm{pFe}$.

\section{New Insights}

\section{Freeze-Thaw Reactions in Ice}

Freezing concentrates water and solutes into microenvironments at grain boundaries (Kim et al., 2010). Freezing may also conserve gases hence creating oxic environments where the rapid oxidation of pyrite and other $\mathrm{Fe}(\mathrm{II})$ minerals may occur (see Oxidation of pyrite and Fe(II) silicates). Figure 1 summarizes the potential reactions that could occur in a sediment-rich, watery layer or cavity enclosed in ice, which is close enough to the ice surface to allow the transmission of UV radiation and to allow temperature fluctuations due to solar heating and freezing.Temperature changes arise because solar energy is absorbed more readily in sediments than in the enclosing ice (which conducts heat less readily). Weathering reactions slow or stop when solar radiation diminishes and temperatures fall to freezing.

Warmer intervals initiate thaw cycles and iron mineral reactions (equations 1,3 , and 4 ) occur. However, $\mathrm{Fe}^{3+}$ addition to the enclosed water may be limited by saturation with ferrihydrite where oxic conditions exist. As freezing is initiated, so concentrations of dissolved iron increase, and $\mathrm{Fe}^{3+}$ may be adsorbed to ice surfaces, precipitated as ferrihydrite (or with other minerals) and aggregated into CNFe. This removal of $\mathrm{Fe}^{3+}$ into sediment and/or ice may not be fully reversed when ice melts and undersaturation with respect to ferrihydrite then exists. Hence $\mathrm{Fe}^{3+}$ is then below saturation levels and further dissolution can occur. Repetitive freeze/thaw cycles can thus continue to add $\mathrm{Fe}$ to ice, water and/or sediment.

There are two sets of Arctic iceberg data (see Particulate Fe speciation). One set utilizes 30 iceberg samples from Greenland (Raiswell et al., 2016) but excludes samples with $>0.1$ wt. \% FeA (see Particulate iron speciation controls in icebergs). The other data set uses 34 samples (those embedded in ice) from icebergs in Kongsfjorden (Svalbard; Hopwood et al., 2017). These two iceberg data sets have different mean $\mathrm{FeA}$ contents but combining the two data sets produces a mean of $0.032 \pm 0.024$ wt. \%. Including the samples from Raiswell et al. (2016) with $>0.1 \% \mathrm{FeA}$ produces a higher mean of $0.059 \pm 0.085$ wt. \%. Neither estimate is significantly different from the FeA content of sediment entombed in glaciers.

\section{Particulate Iron Speciation Controls in Icebergs}

Pyrite is present in a wide variety of sedimentary, igneous, and metamorphic rocks although average crustal $\mathrm{S}$ contents are low (0.02 to 0.24 wt. \%; Faure, 1998). Hence ferrihydrite should be a common subglacial weathering product, irrespective of bedrock geology. However, ferrihydrite (measured as FeA) is not found in large concentrations in ice-hosted sediments (Table 3). There could be several reasons for this; the initial pyrite concentrations in the glacial bedrock might have been low and entombment in ice may have minimized water contact (and thus weathering and alteration). However, Schwertmann et al. (2004) have shown that the transformation of ferrihydrite $(\mathrm{FeA})$ to goethite/hematite $(\mathrm{FeD})$ occurs at low temperatures (half-lives at $4^{\circ} \mathrm{C}$ range from $\sim 30$ year at $\mathrm{pH} 6$ to $\sim 3$ year at $\mathrm{pH}$ 8). Transformation can be prevented by adsorption of Si and organic matter (Jones et al., 2009). However, the ferrihydrite formed in a subglacial environment (where contact with organic matter is limited and where the alteration kinetics are slow) may be preserved in ice and may remain potentially bioavailable.

Raiswell et al. (2016) found that the FeA contents of Arctic and Antarctic samples of iceberg sediments were significantly higher than glacier-hosted sediments. The icebergs were not all calved from the land-based glaciers that were sampled but it 


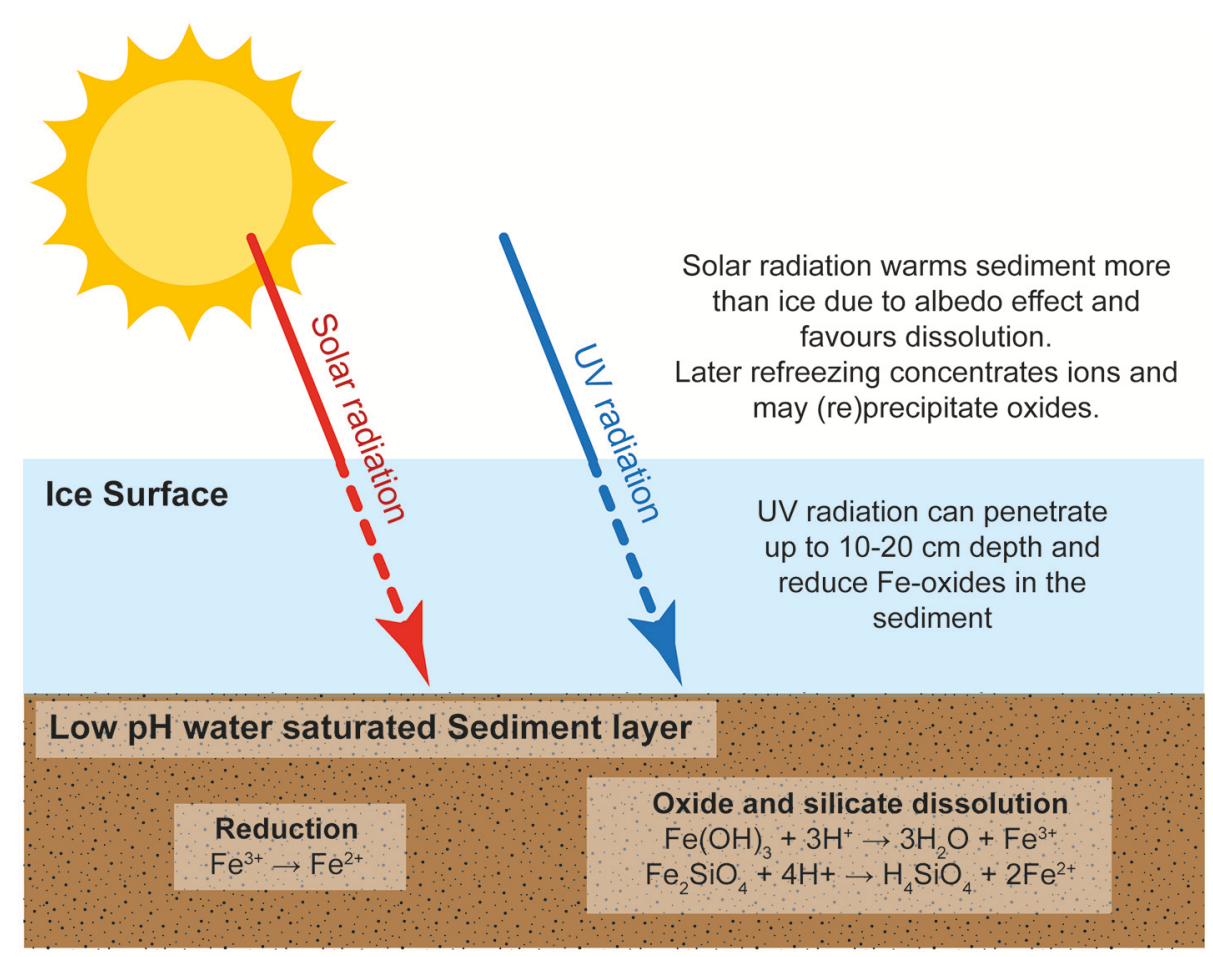

FIGURE 1 | Schematic representation of the redox and dissolution/precipitation cycles that occur in an ice-hosted sediment layer near the ice surface.

was hypothesized that the iceberg sediments had been weathered and altered during post-calving transport due to interactions with seawater and temperature fluctuations that induced melting, weathering and re-freezing (see Freeze-thaw reactions in ice).The difference between sediments in glaciers and icebergs that Raiswell et al. (2016) identified is here re-examined using the databases shown in Table 3. The new means and standard deviations for the sediments from icebergs $(0.032 \pm 0.024$ wt. \%) and glaciers $(0.042 \pm 0.059$ wt. \%) are not significantly different. This contradiction with the Raiswell et al. (2016) conclusion mainly arises from separating out the samples $>0.1 \%$ FeA from the iceberg data. Plots of FeA against FeD (Figure 2) show two different relationships between $\mathrm{FeA}$ and FeD. One relationship shows persistently low concentrations of FeA ( $<0.1$ wt. \%) over relatively large concentrations of $\mathrm{FeD}$ (ranging from 0.1 to 1.2 wt. \%). There are several explanations for the low variations in $\mathrm{FeA}$ over a large range in $\mathrm{FeD}$; these samples may originally have contained little pyrite, or may have been little weathered, or sufficient time may have passed for all FeA to have been altered to $\mathrm{FeD}$. These circumstances will all produce sediments with low values of FeA associated with high values of FeD.

However, Figure 2 also shows that nine iceberg sediments have $\mathrm{FeA}>0.1 \mathrm{wt}$. \% (and up to 0.5 wt. \%) over a wide range of FeD (0.2 to 1.2 wt. \%). These samples crudely fit a series of curves, each with a limb of rising FeA that reaches a peak and then declines as FeD continues to increase. Such curves would be expected in a system where pyrite initially weathers to form FeA faster than FeA alters to FeD. No single curve would be expected as each ice-enclosed microenvironment will evolve over a different pathway depending on the amount of pyrite, the rate of weathering and the rate of alteration to goethite/hematite. Figure 2 shows that these temporarily enhanced proportions of FeA can produce relatively high ratios of FeA/FeD. Short transport times of icebergs to the marine environment will favor the preservation of FeA and thus some iceberg sediments with high ratios of FeA/FeD may be released to the open ocean.

\section{Synthesis}

Sediment Fe speciation data suggest the following controls on composition, which require validation.

(i) The presence of schwertmannite demonstrates that pyrite oxidation occurs in subglacial systems and produces potentially bioavailable ferrihydrite measured as FeA. Concentrations of FeA in ice are low, either because glacial bedrock contains little pyrite, or oxidative weathering of pyrite was limited.

(ii) Ferrihydrite entombed in ice transforms slowly to goethite/hematite (measured as FeD). Measurements of FeA and FeD in icebergs are consistent with a model where temporarily high concentrations of FeA exist prior to their slow transformation to FeD. Further studies of icebergs are required to confirm this model, which suggests that models of FeA release by iceberg melting may need to incorporate a time-decay function based on the kinetics of ferrihydrite conversion to goethite/hematite. 


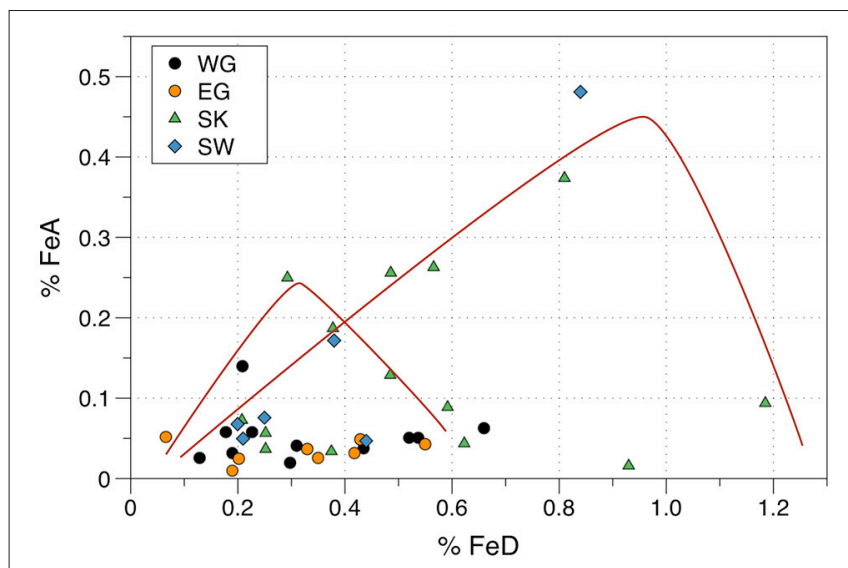

FIGURE 2 | Relationship between FeA wt. \% and FeD wt. \% for Arctic iceberg sediments. Data from Raiswell et al. (2016). Localities are Wallensbergfjorden (Svalbard, SW), Kongsfjord (Svalbard, SK), Sermilk (East Greenland, EG), and Narsarsuaq (West Greenland, WG). Red lines represent possible pathways of FeA formation by weathering and loss by transformation in different iceberg microenvironments.

\section{IRON BEHAVIOR DURING SUBGLACIAL FREEZING}

\section{Background}

Complex interactions occur between ions, gases, ice and water during freezing. The major ions are not readily incorporated into the ice lattice and the remaining unfrozen water may thus become highly concentrated in solutes. Consistent with this, observations of natural systems show that the water first released from melting ice is enriched in the major cations by 3-5 times compared to the initial fluids (producing an "ionic pulse”; e.g., Lilbaek and Pomeroy, 2008; Telling et al., 2014). Rates of solute exclusion are influenced by the rate of freezing and the morphology of the ice-water interface. Fast rates of freezing produce solute-rich boundary layers at the ice-water interface that favor incorporation into ice, unless the layers are removed by diffusion, turbulence or convection (Killawee et al., 1998).

Experimental work with cations has mainly focused on $\mathrm{Ca}^{2+}$ $\mathrm{HCO}_{3}^{-}$waters (Hallet, 1976; Killawee et al., 1998). There are no studies that consider the behavior of Fe during subglacial freezing but important clues are provided by Killawee et al. (1998), who conducted freezing experiments with varying initial $\mathrm{CaCO}_{3}$ saturation states and varying concentrations of the major cations. No attempt was made to remove boundary layer effects. All the experiments showed $\mathrm{CaCO}_{3}$ precipitation and steady increases in $\mathrm{Ca}, \mathrm{Mg}$, $\mathrm{Sr}$ and $\mathrm{Na}$ as freezing progressed. The combination of calcite precipitation plus freezing caused the $\mathrm{pCO}_{2}$ to rise steadily up to values of $\sim 10^{-2.5} \mathrm{~atm}$. The concentration increases for $\mathrm{Na}$ $(\sim 3.5 \times)$ were larger than those for $\mathrm{Ca}, \mathrm{Mg}$, and $\mathrm{Sr}$ (which were being removed into the precipitating calcite), nevertheless $\mathrm{Ca}$, $\mathrm{Mg}$, and Sr were still enriched in the final solution by a factor of $\sim 2.5 \times$. Relatively low rates of freezing reduced boundary layer effects (and thus incorporation into ice) and allowed ions at the ice interface to diffuse away into the residual solution. Hence the rate of freezing exerts a significant influence on the extent of concentration (Killawee et al., 1998). These experiments show that progressive freezing increases concentrations in residual water but even ions removed by mineral precipitation continued to increase in the residual, freezing water.

\section{New Insights}

In this section the Geochemists Workbench is used to explore the behavior of iron during freezing. The Geochemists Workbench uses Pitzer equations to derive the ion interaction parameters in concentrated solutions. The models envisage a water-filled cavity enclosed in ice with no connections to external fluids or the atmosphere (a closed system), from which water is progressively removed (following the approach of Elsenousy et al., 2015). It is assumed that;

(a) The water is maintained at $0^{\circ} \mathrm{C}$ throughout by slow freezing (no boundary layer effects),

(b) Closed system freezing removes only water (gases and ions are conserved in the residual water, except where mineral dissolution or precipitation occurs as described below),

(c) Excess ferrihydrite is always present and the waters are maintained in equilibrium with ferrihydrite throughout freezing.

The absence of boundary layer effects in (a) minimizes the concentration of aqFe, whereas the presence of a closed system in (b) maximizes the concentration of aqFe in the freezing water whilst (c) limits the accumulation of aqFe by maintaining saturation with respect to ferrihydrite. The models take no account of kinetics and kinetic inhibition of precipitation is likely to cause species concentrations to be higher than plotted in Figures 3-10. However, many different models could be constructed using different assumptions (temperature and water composition etc) and the present models should be regarded as only exploratory. Our purpose here is simply to investigate the aqFe concentrations that could be reasonably be achieved during subglacial freezing in the absence of organic complexes and $\mathrm{Fe}$ mineral dissolution (except as required to maintain equilibrium with ferrihydrite). Note that the initial composition is based on an unpolluted rainwater (Table 4) that includes only the major inorganic cations and anions. The models examine how freezing influences the concentration of aqFe species. Some proportion of aqFe may also be removed by aggregation to CNFe and/or $\mathrm{pFe}$ (but quantifying these contributions is impossible).

Figures 3, 4 show the first changes produce vertical trends in $\mathrm{pH}$ and dissolved $\mathrm{pCO}_{2}$ as the carbonate system in the water equilibriates with the atmosphere at $0^{\circ} \mathrm{C}$. Carbonates precipitate (mainly $\mathrm{CaCO}_{3}$ plus a lesser amount of dolomite) which produce the sharp linear increases in $\mathrm{pCO}_{2}$ and decreases in $\mathrm{Ca}^{2+}$ (Figure 5) and $\mathrm{pH}$. When $\sim 50 \%$ of the water has been lost and the $\mathrm{pH}$ is $\sim 5.55$, the dominant dissolved $\mathrm{Ca}$ species is the $\mathrm{CaHCO}_{3}^{+}$complex (Figure 5), the concentration of which continues to increase through the remaining water loss by freezing. Carbonate precipitation continues but the rates of $\mathrm{Ca}$ removal by precipitation, and additions by freezing, are similar and thus the concentration of Ca remains uniform. The lowest $\mathrm{pH}$ reached is $\sim 5.47$ after the removal of $\sim 70 \%$ of the water. 


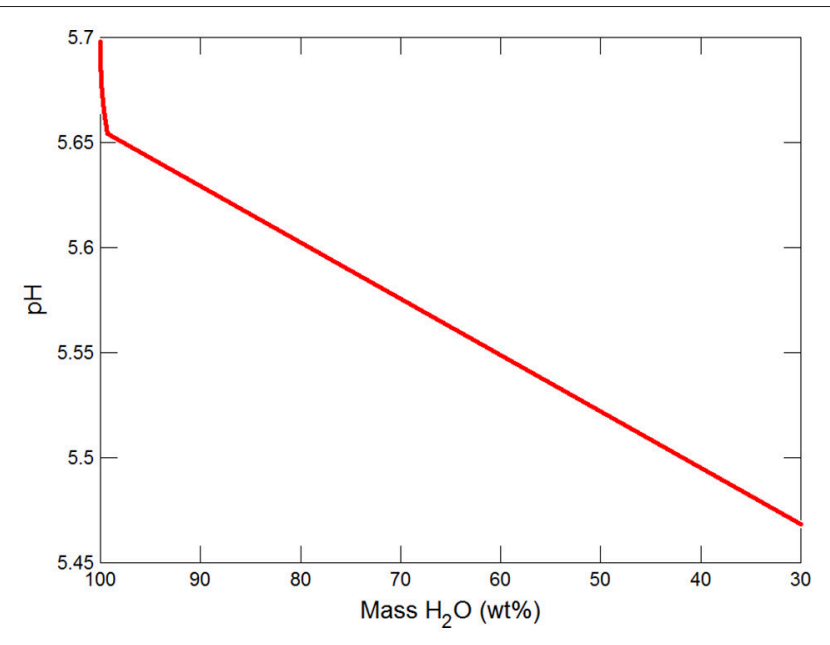

FIGURE 3 | Variations in pH during freezing of glacial water.

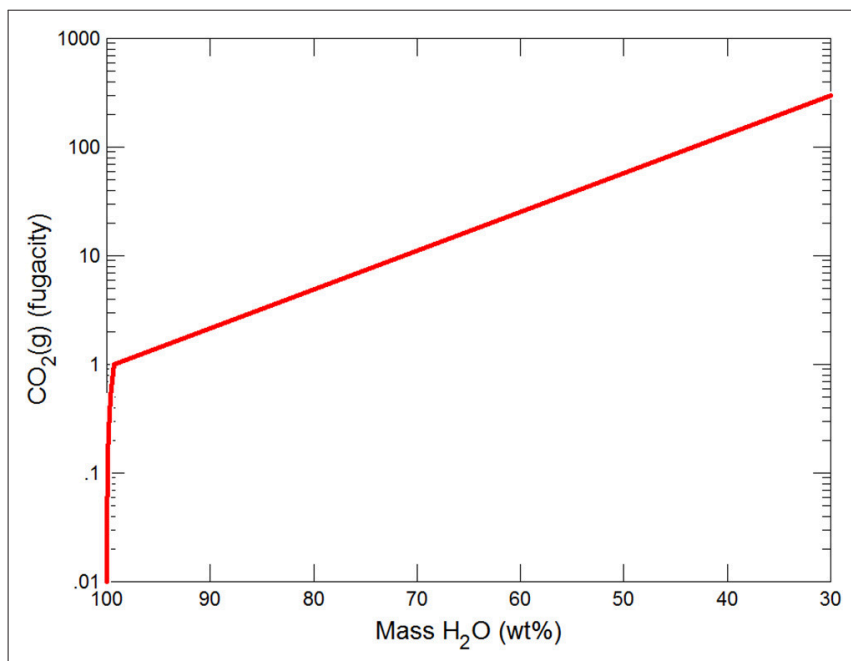

FIGURE 4 | Variations in $\mathrm{pCO}_{2}$ during freezing of glacial water.

Figure 6 shows that $\mathrm{Fe}(\mathrm{OH})^{2+}$ and $\mathrm{Fe}(\mathrm{OH})^{+}$complex ions are the dominant dissolved iron species over the $\mathrm{pH}$ range from 5.7 to 5.47. Iron chloride complexes increase during freezing as chloride concentrations increase, but these species never become quantitatively significant.

\section{Synthesis}

The models require further validation but are broadly consistent with the observations of natural and experimental systems in that;

(i) Significant solute concentration increases can be achieved during subglacial freezing and are accompanied by decreases in $\mathrm{pH}$ and increases in $\mathrm{pCO}_{2}$.

(ii) The models predict aqFe concentrations in this subglacial system, in equilibrium with ferrihydrite, that are maintained at $\sim 4 \times 10^{-8} \mathrm{mM}$ or $\sim 0.04 \mathrm{nM}$ throughout freezing.

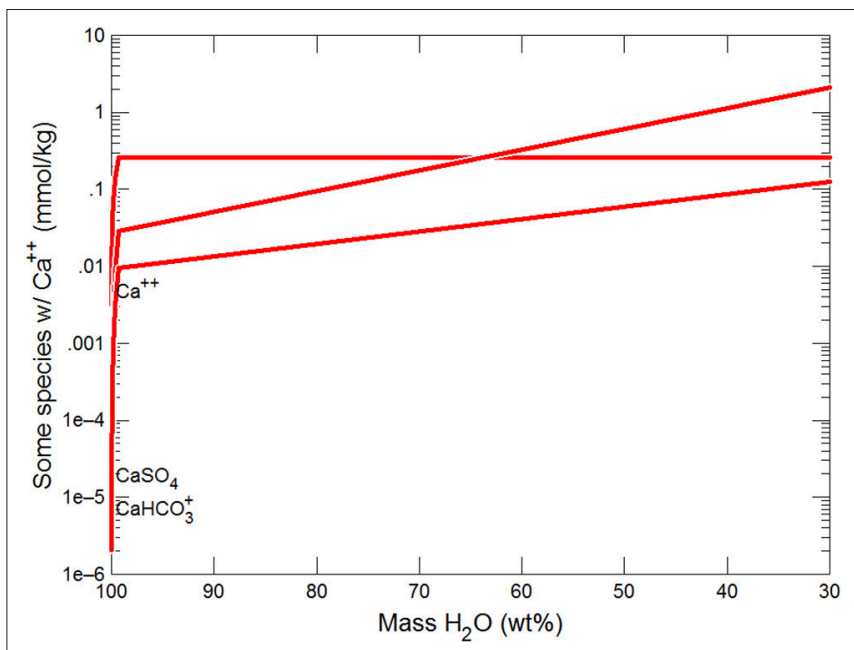

FIGURE 5 | Variations in Ca species during freezing of glacial water. Final solution has $\mathrm{Ca}$ bicarbonate $>\mathrm{Ca}>\mathrm{Ca}$ sulfate.

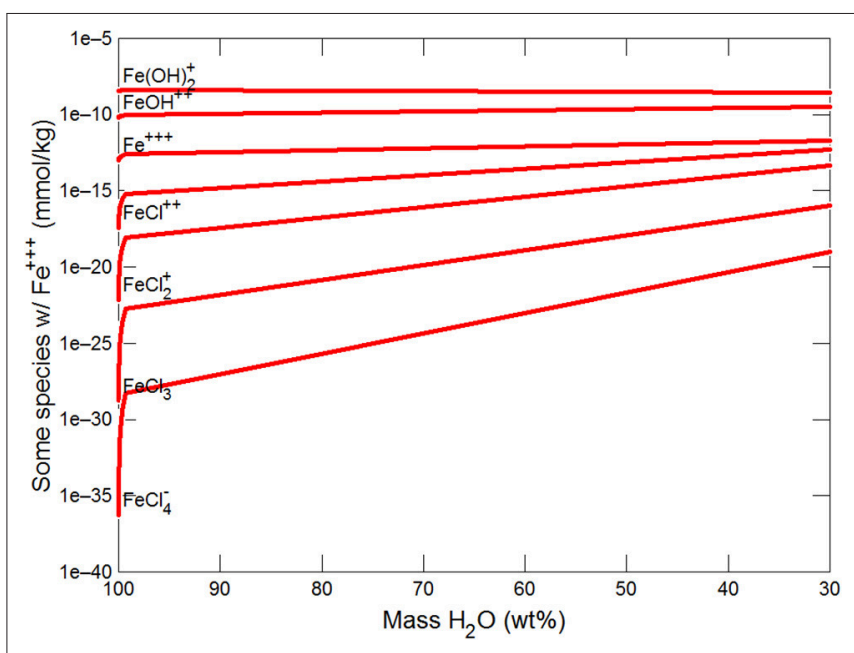

FIGURE 6 | Variations in Fe species during freezing of glacial water.

However, the nanomolar levels of sFe in ice ( $<1$ to $20 \mathrm{nM}$; Table 2) are many orders of magnitude higher than the model aqFe predictions and appear too high to be reached by simple freezing.

(iii) Higher aqFe values would result if high concentrations of complexing species (chloride, EPS etc) were present (as in the seawater models, see New Insights in following section) and/or continued dissolution of Fe-bearing minerals occurred (especially in anoxic and/or acidic conditions), assisted by UV radiation.

(iv) Alternatively high sFe values from ice may result the measurement methodology which includes nanoparticulate $\mathrm{Fe}<0.02 \mu \mathrm{m}$ and Fe species desorbed from sediment during melting.

(v) High CNFe values in ice and meltwaters (200$9000 \mathrm{nM}$ ) are considerably in excess of ferrihydrite 


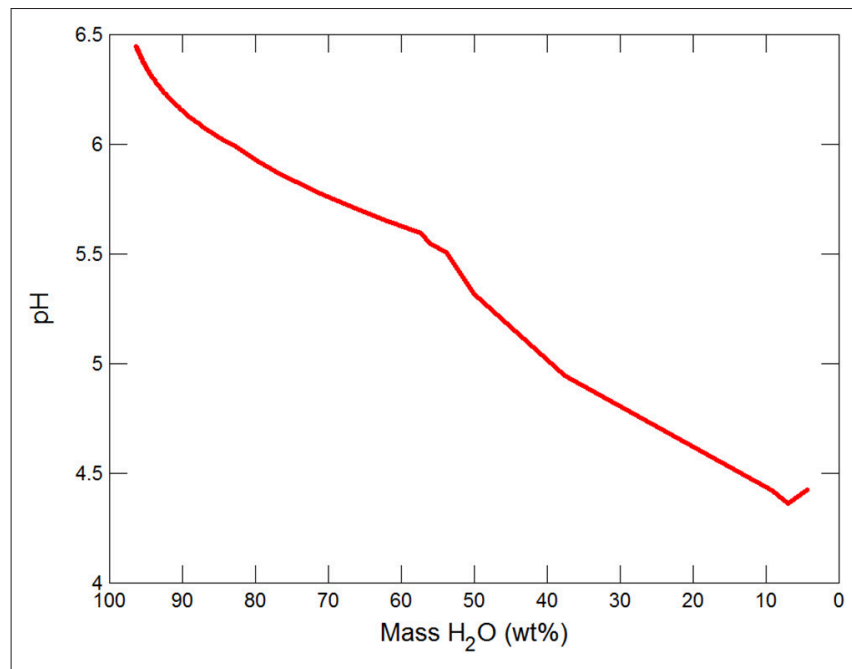

FIGURE 7 | Variations in pH during freezing of seawater.

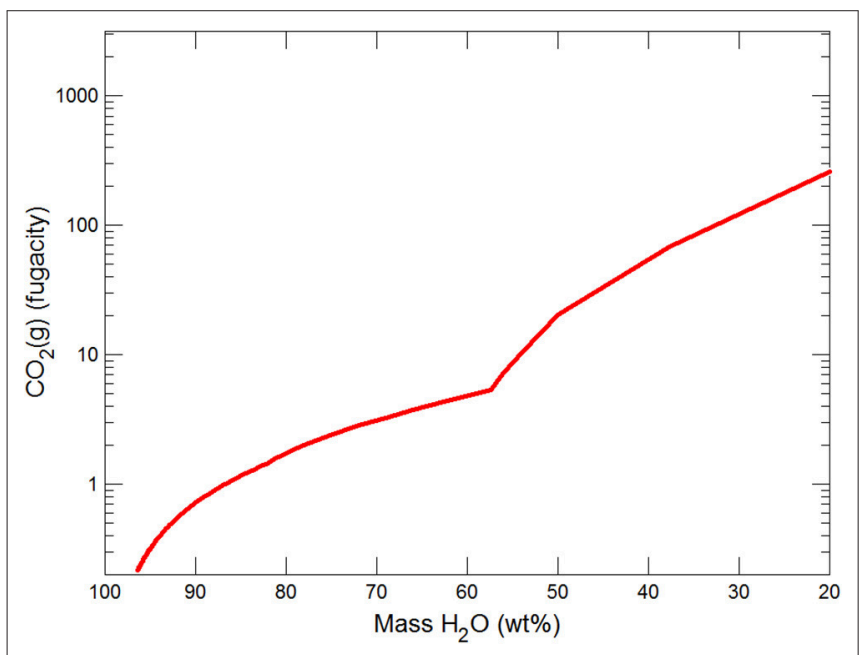

FIGURE 8 | Variations in $\mathrm{pCO}_{2}$ during freezing of seawater.

equilibrium levels and must be mainly present as nanoparticles.

\section{IRON BEHAVIOR DURING SEAWATER FREEZING}

\section{Background}

Sea ice exerts an important role in the iron cycle in the polar regions (Vancoppenolle et al., 2013; Wang et al., 2014; Lannuzel et al., 2016). There are many more measurements of sea ice Fe in the Antarctic than the Arctic but measurements in both regions are too few to characterize adequately a system which is highly variable, both temporally and spatially. In general, however; (i) measurements of $\mathrm{dFe}$ and $\mathrm{pFe}$ in land-fast sea ice are higher than in pack ice due to the increased opportunity for sedimentary inputs, (ii) concentrations of $\mathrm{dFe}$ are higher toward the bottom of

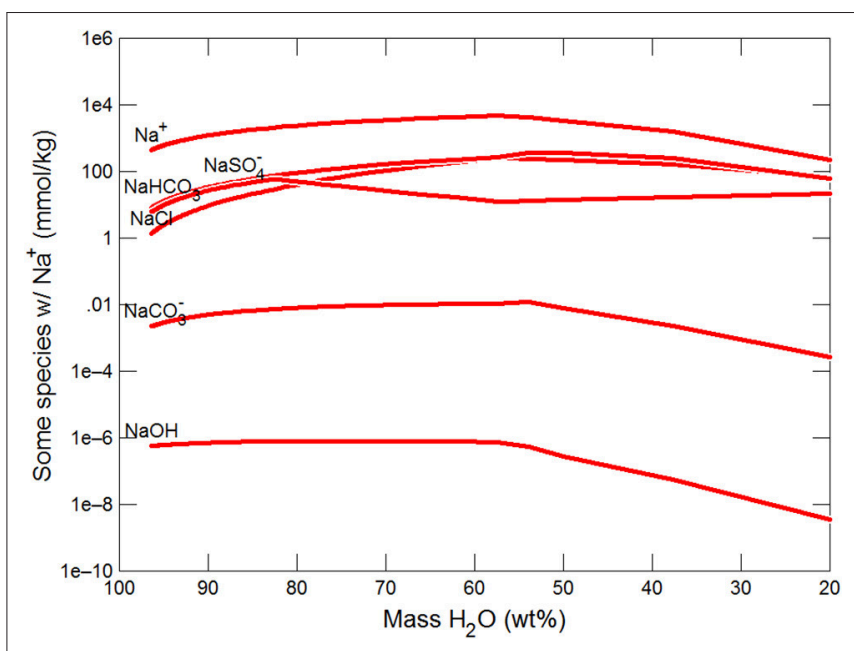

FIGURE 9 | Variations in Na species during freezing of seawater.

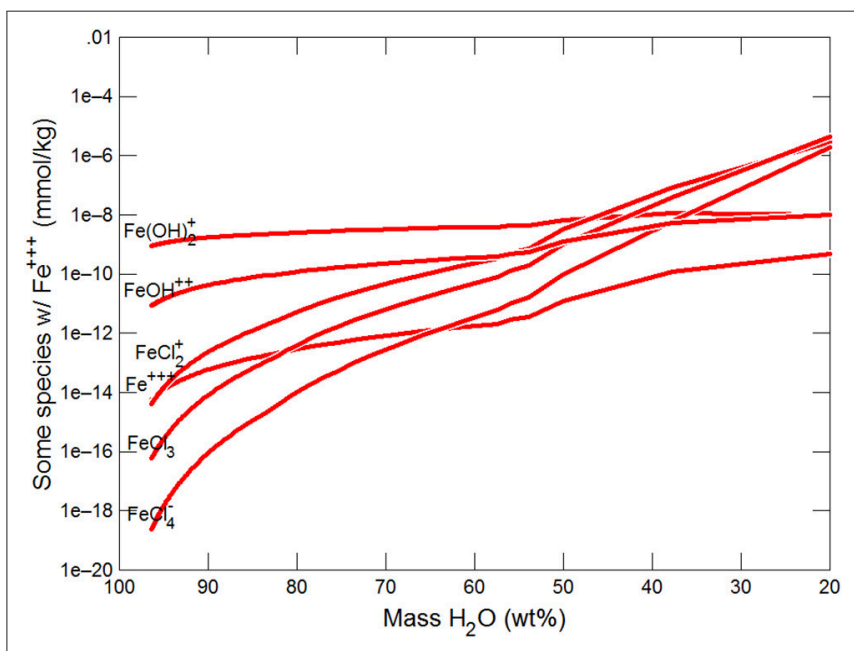

FIGURE 10 | Variations in Fe species during freezing of seawater.

the ice because sea ice algae scavenge Fe from seawater and Fe can be transported vertically downwards by brine drainage, and (iii) the concentration of $\mathrm{dFe}$ in sea ice is several times higher than in the seawater under the ice (Lannuzel et al., 2016). Thus the seasonal release of potentially bioavailable $\mathrm{dFe}$ is able to relieve iron limitation and produce phytoplankton blooms at melting sea ice margins (Vancoppenolle et al., 2013; Wang et al., 2014; Lannuzel et al., 2016).

However, the processes by which $\mathrm{Fe}$ is incorporated into sea ice are not well-known. Wang et al. (2014) suggest three potential mechanisms; (1) dissolved and particulate Fe can be removed from seawater by entrainment during ice formation, (2) Fe-rich particles, colloids, and organic matter are harvested during winter by ice crystals that rise through the water column toward the ice base, forming an iron-rich substrate, and (3) resuspended shelf sediments can also be added to the underlying ice surface and aeolian dust can be deposited on the ice surface and incorporated into the ice. 
Subsequent within-ice processes are also poorly understood. Observations from melted ice sections indicate that $\mathrm{dFe}$ is excluded from ice into brine-rich microenvironments (created by freezing seawater) which are trapped within relatively impermeable winter ice. In spring, sea ice becomes more permeable and $\mathrm{dFe}$-rich brines can then drain into the underlying seawater (Lannuzel et al., 2007, 2014). Both dFe and pFe are believed to exchange with each other within sea ice. Algae and organic compounds incorporated within sea ice have a high affinity for dFe which is thus removed into pFe (Hassler and Schoemann, 2009). Conversely some pFe goes into dFe due to cell lysis, heterotrophic activity and photo-oxidation. Heterotrophic reduction of $\mathrm{Fe}$ (oxyhydr)oxides produces ferrous iron, which can be stabilized by EPS complexes. Leakage of complexed Fe from brine inclusions delivers $\mathrm{dFe}$ to seawater as the ice becomes more permeable during melting.

Experimental and computer modeling studies have been aimed at understanding the sequential chemical changes that occur as seawater is progressively frozen in sea ice. Two main pathways have been identified, depending on whether precipitated minerals are removed from the residual brines (the Gitterman pathway) or are allowed to interact with the brines (the Ringer-Nelson-Thompson or R-N-T pathway). Both pathways sequentially produce mirabilite $\left(\mathrm{Na}_{2} \mathrm{SO}_{4}\right)$, hydrohalite $\left(\mathrm{NaCl} \cdot 2 \mathrm{H}_{2} \mathrm{O}\right)$, sylvite $(\mathrm{KCl})$, and finally $\mathrm{MgCl}_{2} \cdot 12 \mathrm{H}_{2} \mathrm{O}$. The main differences between the two pathways are the non-appearance of gypsum in the R-N-T pathway and minor differences in precipitation temperatures. Subsequent studies of natural and experimental systems (Marion et al., 1999; Geilfus et al., 2013; Butler and Kennedy, 2015) confirm the formation of gypsum and thus favor the Gitterman pathway.

Sea ice is a very heterogeneous medium. Delille et al. (2014) envisage that vertical heterogeneity produces an upper layer with dense ice which is also porous, and a lower layer that contains pockets and channels that may be temporarily or permanently open to seawater. The upper layer can be considered as a closed system where carbonate precipitation occurs and the $\mathrm{pCO}_{2}$ increases due to precipitation and freezing (Delille et al., 2014). Temperatures in the upper layer may reach -20 to $-30^{\circ} \mathrm{C}$ but the lower layer in contact with seawater is much warmer $(-2$ to $-5^{\circ} \mathrm{C}$; Delille et al., 2014; Lannuzel et al., 2016). The models explored here apply only to the upper, closed system layer and examine the potential for aqFe concentrations to be increased by freezing removal of water.

\section{New Insights}

This section follows the modeling approach developed in the section on modeling subglacial waters using Geochemists Workbench. The seawater models use the same initial assumptions as the glacial model but with an initial composition corresponding to average seawater (Table 4). Freezing initially produces precipitation of $\mathrm{CaCO}_{3}$ (with a small amount of dolomite) which together increase $\mathrm{pCO}_{2}$ and dramatically decrease $\mathrm{pH}$ (Figures 7, 8). When the water mass has declined to $\sim 80 \%$, the $\mathrm{Na}^{+}$and sulfate become concentrated to the point where mirabilite precipitates (Figure 9). Figure 9 shows that the concentration of $\mathrm{Na}^{+}$continues to increase due to freezing (even whilst mirabilite precipitates), until the water mass declines to
TABLE 4 | Initial water compositions for freeze models (from Berner and Berner, 1987).

\begin{tabular}{lcc}
\hline Solute & $\begin{array}{c}\text { Rainwater } \\
\text { Composition }\end{array}$ & $\begin{array}{c}\text { Seawater } \\
\text { Composition }\end{array}$ \\
\hline $\mathrm{Na}^{+}$ & $4.0 \mu \mathrm{M}$ & $480.6 \mathrm{mM}$ \\
$\mathrm{K}^{+}$ & $3.0 \mu \mathrm{M}$ & $10.4 \mathrm{mM}$ \\
$\mathrm{Ca}^{2+}$ & $3.0 \mu \mathrm{M}$ & $10.5 \mathrm{mM}$ \\
$\mathrm{Mg}^{2+}$ & $0.17 \mu \mathrm{M}$ & $54.3 \mathrm{mM}$ \\
$\mathrm{Cl}^{-}$ & $4.0 \mu \mathrm{M}$ & $559.4 \mathrm{mM}$ \\
$\mathrm{SO}_{4}^{2-}$ & $4.0 \mu \mathrm{M}$ & $28.9 \mathrm{mM}$ \\
$\mathrm{pH}^{-}$ & 5.7 & 8.1 \\
\hline
\end{tabular}

$\sim 55 \%$ of the initial value. Now hydrohalite is supersaturated and $\mathrm{Na}^{+}$concentrations rapidly decline. As the water mass continues to decline, magnesite precipitates (at $\sim 50 \%$ ), and then sylvite (at $37 \%$ ), by which point the $\mathrm{pH}$ has decreased to $\sim 4.7$. These changes broadly correspond to those observed in the seawater freezing experiments described above. The increasing chloride concentrations enable high concentrations of aqFe to exist as the complexes $\mathrm{FeCl}_{2}^{+}$and $\mathrm{FeCl}_{3}^{\circ}$. Figure 10 shows that $\mathrm{FeCl}_{2}^{+}$ constitutes $\sim 10^{-6} \mathrm{mM}$ or $\sim 1 \mathrm{nM}$ when the water mass has been reduced to $\sim 25 \%$. Note that these concentration levels represent aqFe, which will be lower than sFe (as in the glacial model, see Synthesis in previous section) and substantially less than dFe.

\section{Synthesis}

The model predictions of mineral behavior are broadly consistent with the experimental behavior but modeling has produced some important additional insights that should be re-evaluated. In respect of Fe the models predict that;

(i) High concentrations of aqFe $(\sim 1 \mathrm{nM})$ can be achieved during seawater freezing due to increasing concentrations of chloride which complex Fe and retain aqFe in solution. These aqFe concentrations are at the upper end of the observed concentrations of dFe in Arctic and Southern Oceans (typically $\sim 0.1$ to $1.0 \mathrm{nM}$; Wang et al., 2014).

(ii) Higher aqFe concentrations could be achieved by invoking within-ice biological processes and continued mineral-water reactions and complexation with EPS and/or other organic species (see Lannuzel et al., 2015).

(iii) Fe enrichment would be confined to brine pockets or hotspots that would be irregularly distributed within the upper ice layers. Drainage of these hotspots produces pulses of $\mathrm{Fe}$ enriched water that may be transferred to sea water as the ice melts, becomes more permeable and drains through channels into seawater.

\section{MODIFICATION OF GLACIAL SEDIMENTS DURING TRANSPORT}

\section{Background}

Glacial sediment sources may undergo substantial losses and/or modification during transport into the marine environment. Sediments produced from land-terminating glaciers discharging into meltwater rivers may be altered during passage through the 
pro-glacial environment, especially where there is storage in proglacial lakes (Bhatia et al., 2013; Zhang et al., 2015). However two extreme situations exist for the transport of ice-hosted sediment; one represents glaciers where the main ice mass loss is directly into the ocean, and the other occurs where glaciers enter long fjords (up to $150 \mathrm{~km}$ in length) where the main ice mass loss is by melting into the fjord (Hopwood et al., 2015; Straneo and Cenedes, 2015). In this latter case, two main processes have been identified that have the potential to alter the speciation of iron and/or its delivery into the marine environment; (a) circulation patterns in fjords may diminish, or even prevent, the export of ice-hosted iron species into coastal waters (e.g., Hopwood et al., 2016, 2017), and (b) passage through a salinity gradient assembles meltwater sFe and CNFe into aggregates that can slowly sediment out before entry into coastal waters (e.g., Hawkings et al., 2014; Schroth et al., 2014).

\section{Some Challenging Problems}

Many glaciers in the Arctic terminate in fjords, which can be up to $150 \mathrm{~km}$ in length (Straneo and Cenedes, 2015). Seasonal discharge from the Greenland Ice Sheet creates strong lateral and vertical gradients in the physical and chemical properties of water along these fjords. Hence icebergs and meltwaters (and their associated sediments) derived from fjord-terminating glaciers will be affected by complex interactions between tides, density driven seawater inflows, wind patterns and freshwater glacial melt (Meire et al., 2016).

Fjord-terminating glaciers supply meltwater in two ways; supraglacial drainage off the glacier forms a fresh water surface layer (which is a relatively minor contribution) whilst most melting produces a buoyant plume of subglacial meltwater that entrains and mixes with the ambient fjord water as it rises near the glacier front. These plumes can either reach the surface water or travel below the surface at their neutral buoyancy level (Straneo and Cenedes, 2015). In Greenland, highly turbid plumes reaching the surface have been observed at some tidewater glaciers, at least for some part of the melt season (Meire et al., 2017; Kanna et al., 2018). However other studies have found only mid-depth intrusions of glacially modified water (Mortensen et al., 2011) and the impact of this on the transport of Fe is currently unknown. Plume behavior is likely to be temporally variable with buoyancy effects controlled by the magnitude of the subglacial discharge and the salinity and temperature of the fjord water at depth. A strong vertical stratification may prevent rising sub-glacial meltwater (and the associated $\mathrm{Fe}$ ) from mixing into surface water. These complexities are illustrated in the example discussed below.

\section{Godthabsfjord (SW Greenland)}

Cold subglacial discharge in Godthabsfjord has been observed rising from $<100 \mathrm{~m}$ to mix with fjord water that became trapped beneath a low salinity surface layer (Mortensen et al., 2013). However, surface waters in Godthabsfjord do transport glacial particulate material (and associated $\mathrm{Fe}$ ) out of the fjord although the precise origin these sediments is not clearly established. Figure 11 shows data from Hopwood et al. (2016) who measured DFe (filtered $<0.2 \mu \mathrm{m}$; comprising sFe plus CNFe, see Table 1) and TDFe (unfiltered and acidified to $\mathrm{pH}$ 2; comprising sFe, $\mathrm{CNFe}$ and some leached particulate Fe, see Table 1). This data allows particulate Fe to be estimated as (TDFe-DFe), which can be plotted against turbidity (measured by Optical Back Scattering or OBS). The LT samples are from downstream of Lake Tasersuaq and have low ratios of (TDFe-DFe)/OBS due to high turbidity arising from a particle plume. This plume was interpreted by Hopwood et al. (2016) as resulting from re-suspended mud flat pro-glacial sediments. However, headwaters with high particulate loads also enter Lake Tasersuaq to the north of where the LT samples were taken, sourced from a large land-terminating glacier. Furthermore, Meire et al. (2017) have observed surface water samples up-fjord from LT which have high particulate loads derived from the Kangiata Nunaata Sermai and Akullersup Sermia glaciers. These glaciers may thus be the source of some, or all, of the high Fe particulate material in the LT samples.

Whatever their source, the plot of the LT samples trends up to the low salinity GF samples defining a rise in (TDFe$\mathrm{DFe}$ )/OBS that reflects declining OBS, due to the sedimentation of coarser material, which produces particulate iron enrichment. The remaining GF samples show a uniform trend in (TDFe$\mathrm{DFe}$ )/OBS that runs from $\sim 5-32 \mathrm{ppt}$ salinity (with no evidence for Fe losses through the salinity gradient, see below). Interestingly, there is a sharp anomalous decline in this relationship between a salinity of 27-30 ppt. The reasons for this are unknown, and the trend over a salinity of $30 \mathrm{ppt}$ follows that below 27 ppt. These two stations (GF4, GF5) are close to the Greenland capital city of Nuuk and therefore there could be a localized higher turbidity influence from the settlement. In the present context, Figure 11 clearly shows that the surface waters in Godthabsfjord can transport fine, iron-enriched glacially-derived particulates out of the fjord. However, dissolved and particulate glacial Fe export may be impeded when deep turbid, subglacial melt cannot reach the surface waters and when dominant southerly winds and warm surface waters ensure that most ice is trapped, and melts, within the fjord surface waters (Hopwood et al., 2016). The variable role of subsurface upwelled glacial water in supplying nutrients to the fjord surface waters requires further study.

\section{The Influence of Salinity Gradients}

Meltwaters emerging into seawater pass through a salinity gradient where aggregation removes a significant proportion of dFe. Zhang et al. (2015) found losses of $\sim 90 \%$ for dFe in meltwaters passing through the Kongsfjorden estuary, with only $4.7 \mathrm{nM}$ of $\mathrm{dFe}$ (stabilized by organic complexes) actually reaching seawater. Hence losses through estuaries are commonly assumed to be $\sim 90 \%$ for $\mathrm{dFe}$ in meltwater (Hawkings et al., 2014; Schroth et al., 2014). The removal of $\mathrm{dFe}$ from river water varies widely from 75 to $>95 \%$ but aggregation may only affect CNFe and not aqFe. Dai and Martin (1995) have shown that aqueous Fe $(<$ $3 \mathrm{~nm}$ ) shows a linear, conservative mixing trend with increasing salinity whereas their colloidal/nanoparticulate fraction $(3 \mathrm{~nm}$ to $0.4 \mu \mathrm{m}$ ) shows a concave, non-conservative trend of flocculation and removal with increasing salinity.

The removal of $\mathrm{dFe}$ (mainly $\mathrm{CNFe}$ ) will be influenced by compositional differences such as particle composition 


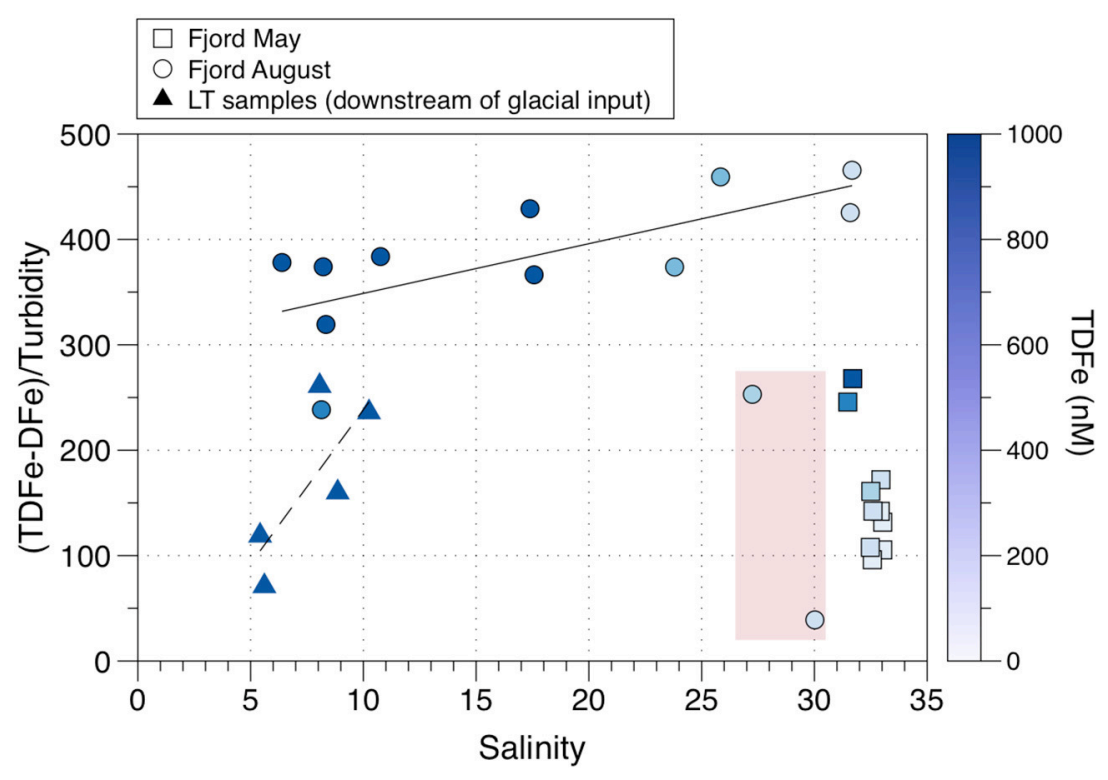

FIGURE 11 | Variations in the ratio of (TDFe-DFe)/Turbidity (measured as OBS or Optical Back Scattering) with salinity in Godthabsfjord (Greenland). The dash lined indicates a linear best fit of LT samples (low salinity, high turbidity meltwater plume), and the solid line indicates a best fit of other August fjord samples (excluding outlier stations GF4 and GF5, highlighted in red). Data from Hopwood et al. (2016).

and ligand availability, but it has also been suggested that aggregation is more efficient in summer than winter (Mayer, 1982). Laboratory studies (Markussen et al., 2016) also show that the kinetics of the flocculation and aggregation process are linked to the labile Fe content of the particles (as measured by extraction with ammonium oxalate at $\mathrm{pH} 3$; see Particulate $\mathrm{Fe})$. Increased levels of $\mathrm{dFe}$ increase the surface area of the flocs and decreases their density. In situ observations in Disko Fjord showed that the horizontal transport of particulate labile Fe occurs partly because $\mu \mathrm{M}$ levels of $\mathrm{dFe}$ (essentially all CNFe; see Table 1) produce particles as larger flocs but with a lower density that sediment more slowly (Markussen et al., 2016). Such a mechanism might produce the Fe-enriched particles observed by Hopwood et al. (2016) at high salinities in Godthapsfjord. Further studies of particulate Fe measurements in relation to particulate concentration (mass/volume, turbidity) are needed to ascertain the influence of the density alterations observed by Markussen et al. (2016) in other fjord systems.

\section{Synthesis}

The temporal and spatial variations in fjords present challenging problems for recognizing and quantifying glacial ice-hosted Fe sources, which will require that mineralogy and speciation are considered within a rigorous oceanographic framework. Complications may also arise from the addition of multiple $\mathrm{dFe}$ sources, including pro-glacial drainage to surface fjord waters and benthic recycling to bottom waters (e.g., Wehrmann et al., 2014). Removal processes through salinity gradients also need to pay more attention to speciation to distinguish between $\mathrm{sFe}$ and $\mathrm{CNFe}$ and examine their different behavior through a salinity gradient.

\section{CONCLUSIONS}

Accurate estimates of bioavailable $\mathrm{Fe}$ are at present impossible but the optimum measure of bioavailable $\mathrm{Fe}$ is sFe (the $<0.02 \mu \mathrm{m}$ fraction of $\mathrm{dFe}$ ). However, the larger CNFe fraction contains ferrihydrite that has been shown experimentally to be bioavailable. In general the $\mathrm{CNFe}$ fraction is poorly characterized and the routine use of high resolution microscopy techniques would provide valuable information about the form of $\mathrm{CNFe}$ and its potential bioavailability. At present the optimum bioavailability targets are weakly-bound, surface Fe(II) in aluminosilcates (and other minerals), and $\mathrm{Fe}$ (II) or Fe(III) in ferrihydrite. These potentially bioavailable species can be extracted by ascorbic acid (as FeA), thus we recommend more widespread use of this procedure.

Improved speciation data obtained here show that the ranges of iceberg and meltwater sFe are comparable (tens of nanomolar) but icebergs contain an order magnitude more CNFe (hundreds of nanomolar), as compared to thousands of nanomolar in meltwaters. Meltwater suspended sediments also contain an order of magnitude more FeA than iceberg (or glacier) sediments but the FeD contents of iceberg sediment and suspended sediments are not significantly different.

Iron minerals encased in ice are not inert but reaction kinetics are slow. The most rapid reactions involve the oxidation of pyrite to form iron (oxyhydr)oxides, including nanoparticulate ferrihydrite. The iron (oxyhydr)oxides in ice-hosted sediments can also be reduced by UV radiation, which can penetrate up to $10 \mathrm{~cm}$ in ice. Near surface sediment layers in ice are also warmed by solar radiation and freeze-thaw cycles are able to facilitate dissolution of iron (oxyhydr)oxides and transfer sFe and CNFe to 
ice. The ferrihydrite produced by weathering in ice alters slowly to goethite/hematite, so decreasing $\mathrm{FeA}$ and increasing FeD. The ratio $\mathrm{FeA} / \mathrm{FeD}$ thus increases during the early stages of ice processing, then declines as FeA is altered to goethite/hematite. The delivery of FeA from icebergs is therefore determined by the rate of alteration of $\mathrm{FeA}$ to $\mathrm{FeD}$ in relation to the transit time of icebergs.

The reactions occurring as water is frozen have been modeled in subglacial environments, assuming an initial rainwater composition which is maintained at saturation with ferrihydrite. After removal of $\sim 70 \%$ of water the $\mathrm{pH}$ has declined to $\sim 5.5$ and aqFe concentrations are substantially increased up to $\sim 0.04 \mathrm{nM}$. AqFe concentrations are not directly comparable to measurements of $\mathrm{sFe}$ in ice (tens on nanomolar) which include some nanoparticulate $\mathrm{Fe}$ as well aqFe. Nevertheless, the modeled values are so far below ice sFe concentrations as to indicate that simple freezing in subglacial systems cannot produce the observed sFe values. The models, therefore, point to the involvement of redox and/or dissolution reactions with iron (oxyhydr)oxides and the presence of species that could complex $\mathrm{Fe}$, and retain it in solution.

The same approach was used to model the reactions that occur in sea ice, using a starting composition of seawater that is maintained at saturation with ferrihydrite. After the removal of $\sim 70 \%$ of water the residual brines have declined to a $\mathrm{pH} \sim 4.7$ and there are substantial increases in aqFe to $\sim 1 \mathrm{nM}$, due to the stabilization of aqFe as chloride complexes. These aqFe values are numerically comparable to dFe values in surface seawater in the polar regions, although aqFe values do not include the $\mathrm{CNFe}$ measured as $\mathrm{dFe}$. Freezing of seawater can clearly play an important role in generating concentrations of $\mathrm{dFe}$ that are able to fuel productivity increases when $\mathrm{Fe}$ is released by melting at sea ice margins.

The delivery of ice-hosted Fe from glacial and iceberg sediments to the open ocean is considerably dampened where glaciers terminate in long fjords. Circulation patterns may hamper the incorporation of sediments into surface outflows of water and particulate material is removed from the water column. Glaciers terminating in, or close to, coastal waters also lose $\mathrm{CNFe}$ during passage through a salinity gradient. Estimates of losses (75-95\%) are based on river systems may not be appropriate analogs for meltwaters in fjords. Aggregation losses may be lower due to colder temperatures and changes in particle shape

\section{REFERENCES}

Annett, A., Fitzsimmons, J. N., Seguret, M. J. M., Lagerstrom, M., Meredith, M. P., Scholfield, O., et al. (2017). Controls on dissolved and particulate iron distributions in surface waters of the Western Antarctic shelf. Mar. Chem.196, 81-97. doi: 10.1016/j.marchem.2017.06.004

Annett, A., Skiba, M., Henley, S. F., Venables, H. J., Meredith, M. P., Statham, P. J., et al. (2015). Comparitive roles of upwelling and glacial iron sources in Ryder Bay, coastal western Antarctic Peninsula. Mar. Chem. 176, 21-33. doi: 10.1016/j.marchem.2015.06.017

Baker, A. R., and Croot, P. L. (2010). Atmospheric and marine controls on aerosol solubility in seawater. Mar. Chem. 120, 4-13. doi: 10.1016/j.marchem.2008.09.003 and density may slow sedimentation losses. Fjord systems need intensive study to clarify how mixing and circulation systems control the delivery of sediment Fe and dFe to the coastal ocean.

Sea ice may accumulate substantial concentrations of aeolian dust during glacial intervals (such as the Last Glacial Maximum), when ice coverage persisted for prolonged periods and dust fluxes were high (Maher et al., 2010). Ice processing redox and dissolution reactions, augmented by freezing effects, will occur during storage producing $\mathrm{dFe}$ which can be released at the melting sea ice margins to stimulate productivity enhancements. The role of sea ice in storing and redistributing iron is rarely considered in most modeling studies of the Southern or Arctic Oceans (2016), with two exceptions (Lancelot et al., 2009; Wang et al., 2014 for the Southern Ocean). The freezing model presented here shows that the formation of sea ice has the potential to stabilize Fe, mainly through chloride complexes. The effects of freezing may be enhanced by the presence of organic ligands and by redox and dissolution reactions. The detailed investigation of sea incorporation mechanisms, and within-ice processes, should be a research priority.

\section{AUTHOR CONTRIBUTIONS}

$\mathrm{RR}, \mathrm{JH}$, and MT wrote the initial draft of the paper and all authors contributed to the subsequent and final drafts. JH, JW, and RR collected most of the data. AE provided the freezing models and $\mathrm{RD}$ provided input for literature Fe model discussion.

\section{ACKNOWLEDGMENTS}

$\mathrm{JH}$ and JW were supported by NERC funded PISCES (NE/P003133/1) and a Leverhulme Trust Research Grant (RPG2016-439). JH was additionally supported by the European Union's Horizon 2020 research and innovation programme under the Marie Skłodowska-Curie Actions fellowship ICICLES (grant agreement \#793962). MT wishes to acknowledge NERC support (via grant number GR3/11689). This material is based upon work supported by the National Aeronautics and Space Administration through the NASA Astrobiology Institute under Cooperative Agreement No. NNA15BB03A issued through the Science Mission Directorate. Two reviewers and Andy Mitchell (as editor) have substantially improved the manuscript and their help is much appreciated. in the solubility of iron, aluminium, manganese and phosphorus in aerosol collected over the Atlantic Ocean. Mar. Chem. 98, 43-58. doi: 10.1016/j.marchem.2005.06.004

Banwart, S., Davies, S., and Stumm, W. (1989). The role of oxalate in accelerating the reductive dissolution of hematite $\left(\alpha-\mathrm{Fe}_{2} \mathrm{O}_{3}\right)$ by ascorbate. Coll. Surf. 39, 303-309. doi: 10.1016/0166-6622(89)80281-1

Berner, E. K., and Berner, R. A. (1987). The Global Water Cycle. New Jersey, NJ: Prentice Hall.

Bhatia, M. P., Kujawinski, E. B., Das, S. B., Breier, C. F., Henderson, P. B., and Charette, M. A. (2013). Greenland meltwater as a significant and potentially bioavailable source of iron to the ocean. Nat. Geosci. 6, 274-278. doi: 10.1038/ngeo1746 
Bosch, J., Lee, K. Y., Jordan, G., Kim, K. W., and Neckenstock, R. U. (2012).Anaerobic, nitrate-dependent oxidation of pyrite nanoparticles by Thiobaccillus denitrificans. Environ. Sci. Tech. 46, 2095-2101. doi: $10.1021 /$ es2022329

Boyd, P. W., Mackie, D. S., and Hunter, K. A. (2010). Aerosol iron deposition to the surface ocean- Modes of iron supply and biological responses. Mar. Chem. 120, 128-143. doi: 10.1016/j.marchem.2009.01.008

Boye, M., Nishioka, J., Croot, P., Lann, P., Timmermans, K. R., Strass, V. H., et al. (2010). Significant proportion of dissolved organic Fe complexes in fact is Fe colloids. Mar. Chem. 122, 20-27. doi: 10.1016/j.marchem.2010.09.001

Buck, C. S., Landing, W. M., and Resing, J. A. (2010). Particle size and aerosol iron solubility: a high-resolution analysis of Atlantic aerosols. Mar. Chem. 120, 14-24. doi: 10.1016/j.marchem.2008.11.002

Buck, C. S., Landing, W. M., Resing, J. A., and Lebon, G. T. (2006). Aerosol iron and aluminium solubility in the northwest Pacific Ocean: results from the 2002 IOC cruise. Geochem. Geophys. Geosyst. 7, 1-10. doi: 10.1029/2005GC000977

Butler, B. M., and Kennedy, H. (2015). An investigation of mineral dynamics in frozen seawater brines by direct measurement with synchrotron X-ray powder diffraction. J. Geophys. Res. 120, 5686-5697. doi: 10.1002/2015JC011032

Chen, Y., and and, R. L., Siefert, R.L. (2003). Determination of different types of labile atmospheric iron over remote oceans. J. Geophys. Res. 108, D24,4774, doi: 10.1029/2003JD003515

Dai, M.-H., and Martin, J.-M. (1995). First data on trace metal level and behavior in two major Arctic river-estuarine systems (Ob and Yenisey) and in the adjacent Kara Sea, Russia. Earth Planet. Sci. Lett. 131, 127-141. doi: 10.1016/0012-821X(95)00021-4

De Baar, H. J. W., and de Jong, J. T. M. (2001). "Distribution, sources and sinks of iron in seawater," in The Biogeochemistry of Iron in Seawater, eds D. R. Turner, and K. A. Hunter (New York, NY: Wiley), 123-253.

De Jong, J. T. M., Schoemann, V., Maricq, N., Mattielli, N., Langhorne, P., Haskell, T., et al. (2013). Iron in land-fast sea ice of McMurdo Sound derived from sediment re-suspension and wind-blown dust attributes to primary productivity in the Ross Sea, Antarctica. Mar. Chem. 157, 24-43. doi: 10.1016/j.marchem.2013.07.001

De Jong, J. T. M., Stammerjohn, S. E., Ackley, S. F., Tilson, J.-L., Mattielli, N., and Schoemann, V. (2015). Sources and fluxes of dissolved iron in the Bellinghausen Sea (West Antarctic): the importance of sea ice, icebergs and the continental margin. Mar. Chem. 177, 518-535. doi: 10.1016/j.marchem.2015.08.004

Death, R., Wadham, J. L., Monteiro, F., Le Brocq, A. M., Tranter, M., Ridgewell, A., et al. (2014). Antarctic ice sheet fertilizes the Southern Ocean. Biogeosciences 10, 12551-12570. doi: 10.5194/bgd-10-12551-2013

Delille, B., Vancoppenolle, M., Geilfus, N.-X., Tilbrook, B., Lannuzel, D., Schoemann, V., et al. (2014). Southern Ocean $\mathrm{CO}_{2}$ sink: the contribution of sea ice. J. Geophys. Res. 110, 6340-6355. doi: 10.1002/2014JC 009941

Duprat, L. P. A. M., Bigg, G. R., and Wilton, D. J., (2016). Giant icebergs significantly enhance the marine productivity of the Southern Ocean. Nat. Geosci. 9, 219-221, doi: 10.1038NGEO2533

Elberling, B. (2005). Temperature and oxygen control on pyrite oxidation in frozen mine tailings. Cold Reg. Sci. Tech. 41, 121-133. doi: 10.1016/j.coldregions.2004.09.004

Elsenousy, A., Hanley, J., and Chevrier, V. A. (2015). Effect of evaporation and freezing on the salt paragenesis and habitability of brines at the Phoenix landing site. Earth Planet. Sci. Lett. 421, 39-46. doi: 10.1016/j.epsl.2015.03.047

Faure, G. (1998). Principles and Applications of Geochemistry, 2nd Edn. New Jersey, NJ: Prentice Hall.

Gartman, A., and Luther, G. W. I. I. I. (2014). Oxidation of synthesized submicron pyrite $\left(\mathrm{FeS}_{2}\right)$ in seawater. Geochim. Cosmochim. Acta 144, 96-108. doi: 10.1016/j.gca.2014.08.022

Geilfus, N.-X., Galley, R. J., Cooper, M., Halden, N., Hare, A., Wang, F., et al. (2013). Gypsum crystals observed in experimental and natural sea ice. Geophys. Res. Lett. 40, 1-6. doi: 10.1002/2013GL058479

Gerringa, L. J. A., Aldercamp, A.-C., Laan, P., Thuroczy, C.-E., de Baar, H. J. W., Mills, M. M., et al. (2012). Iron from melting glaciers fuels the phytoplankton blooms in Amundsen Sea (Southern Ocean): iron biogeochemistry. Deep Sea Res. 71-76, 16-31. doi: 10.1016/j.dsr2.2012.03.007

Hallet, B. (1976). Deposits formed by the subglacial precipitation of $\mathrm{CaCO}_{3}$. Geol. Soc. Am. Bull. 87, 1003-1015. doi: 10.1130/00167606(1976)87\&lt;1003:DFBSPO\&gt;2.0.CO;2
Hassler, C. S., and Schoemann, V. (2009). Bioavailability of organically bound Fe to model phytoplankton of the Southern Ocean. Biogeosciences 6, 2281-2296. doi: 10.5194/bg-6-2281-2009

Hawkings, J. (2015). An Investigation into the Production and Export of Nutrients from Glaciers, Ph.D thesis, University of Bristol, Bristol, 220.

Hawkings, J. R., Benning, L. G., Raiswell, R., Kaulich, B., Araki, T., Abyaneh, M., et al. (2018). Biolabile ferrous iron nanoparticles in glacial sediments. Earth Planet. Sci. Lett. 493, 92-101 doi: 10.1016/j.epsl.2018.04.022

Hawkings, J. R., Wadham, J., Tranter, M., Telling, J., Bagshaw, E., Beaton, A., et al. (2016). The Greenland Ice sheet as a hotspot of phosphorus weathering and export in the Arctic. Global Biogeochem. Cycles 30, 191-210. doi: 10.1002/2015GB005237

Hawkings, J. R., Wadham, J. L., Tranter, M., Raiswell, R., Benning, L. G., Statham, P. J., et al. (2014). Ice sheets as a significant source of highly reactive nanoparticulate iron to the oceans. Nat. Commun. 5:3929. doi: $10.1038 /$ ncomms4929

Herraiz-Borreguero, L., Lannuzel, D., van der Merwe, P., Treverrow, A., and Pedro, J.B. (2016). Large flux of iron from the Amery Ice Shelf marine ice to Prydz Bay, East Antarctica. J. Geophys. Res. 121, 6009-6020. doi: 10.1002/2016JC011687

Hopwood, M. J., Bacon, S., Arendt, K., Conneelly, D. P., and Statham, P. J. (2015). Glacial meltwater from Greenland is not likely to be an important source of Fe to the North Atlantic. Biogeochemistry 124, 1-11. doi: 10.1007/s10533-015-0091-6

Hopwood, M. J., Cantoni, C., Clarke, J. S., Cozzi, S., and Achterburg, E. P. (2017). The heterogeneous nature of Fe delivery from melting icebergs. Geochem. Perspect. Lett. 3, 200-209. doi: 10.7185/geochemlet.1723

Hopwood, M. J., Connelly, D. P., Arendt, K. E., Juul-Pedersen, T., Stichcombe, M., Meire, L., et al. (2016). Seasonal changes in Fe along a glaciated Greenlandic fjord. Front. Earth Sci. 4:15. doi: 10.3389/feart.2016.00015

Jickells, T. D., and Spokes, L. J. (2001), Atmospheric inputs to the ocean, in The Biogeochemistry of Iron in Seawater, eds D. R. Turner and K. A. Hunter (New York, NY: Wiley), 123-251.

Jones, A. M., Collins, R. N., Rose, J., and Waite, T. D. (2009). The effect of silica and natural organic matter on the Fe(II)-catalysed transformation and reactivity of Fe(III) minerals. Geochim. Cosmochim. Acta 73, 4009-4433. doi: 10.1016/j.gca.2009.04.025

Kanna, N., Sugiyama, S., Ohashi, Y., Sakakibara, D., Fukamachi, Y. and Nomura, D. (2018). Upwelling of macronutrients and dissolved inorganic carbon by a subglacial freshwater driven plume in Bowdoin Fjord, northwestern Greenland. J. Geophys. Res. Biogeosci. 123:1666-1682. doi: 10.1029/2017JG004248

Killawee, J. A., Farichild, I. J., Tison, J.-L., Janssens, L., and Lorrain, R. (1998). Segregation of solutes and gases in experimental freezing of dilute solutions: Implications for natural glacial systems. Geochim. Cosmochim. Acta 62, 3637-3655. doi: 10.1016/S0016-7037(98)00268-3

Kim, K., Choi, W., Hoffmann, M. R.,Yoon, H. I., and Park, B. K. (2010). Photoreductive dissolution of iron oxides trapped in ice and its environmental implications. Environ. Sci. Tech.44, 4142-4148. doi: 10.1021/es9037808

Kuma, K., and Matsunaga, K. (1995).Availability of colloidal ferric oxides to coastal marine phytoplankton. Mar. Biol. 122, 1-11. doi: 10.1007/BF00349272

Lancelot, C., de Montey, A., Goose, H., Becquefort, S., Schoemann, V., Basquer, B., et al. (2009). Spatial distribution of the iron supply to phytoplankton in the Southern Ocean: a model study. Biogeosciences 6, 2861-2878. doi: 10.5194/bg-6-2861-2009

Lannuzel, D., Grotti, M., Albelmoschi, M. L., and van der Merwe, P. C. (2015). Organic ligands control the concentrations of dissolved iron in Antarctic sea ice. Mar. Chem. 174, 120-130. doi: 10.1016/j.marchem.2015.05.005

Lannuzel, D., Schoemann, V., de Jong, J., Chou, L., Delille, B., Becquevort, S., et al. (2008). Iron study in during a time series in the western Weddell Sea pack ice. Mar. Chem. 108, 85-95. doi: 10.1016/j.marchem.2007.10.006

Lannuzel, D., Schoemann, V., de Jong, J., Tison, J.-L., and Chou, L. (2007). Distribution and biogeochemical behavior of iron in the East Antarctic sea ice. Mar. Chem. 106, 18-32. doi: 10.1016/j.marchem.2006.06.010

Lannuzel, D., van der Merwe, P. C., Townsend, A. T., and Bowie, A. R. (2014). Size fractionation of iron, manganese and aluminium in Antarctic fast ice reveals a lithogenic origin and low iron solubility. Mar. Chem. 161, 47-56. doi: 10.1016/j.marchem.2014.02.006

Lannuzel, D., Vancoppenolle, M., van der Merwe, P. C., de Jong, J., Meiners, K. M., Grotti, M., et al. (2016). Iron in sea ice: Review and new insights. Elementa 4:000138. doi: 10.1/12952/journal.elementa.00130 
Lilbaek, G., and Pomeroy, J. W. (2008). Ion enrichment of snow melt runoff water caused by basal ice formation. Hydrol. Process. 22, 2758-2766. doi: $10.1002 /$ hyp.7028

Lyons, W. B., Dailey, K. R., Welch, K. A., Deuerling, K. M., Welch, S. A., and McKnight, D. M. (2015). Antarctic streams as a potential source of iron for the Southern Ocean. Geology 43, 1003-1006. doi: 10.1130/G36989.1

Maher, B. A., Prospero, J. M., Mackie, D., Gaiero, D., Hesse, P., and Balkanski, Y. (2010). Global connections between desert dust, ocean biogeochemistry and climate. Earth Sci. Rev. 99, 61-97. doi: 10.1016/j.earscirev.2009.12.001

Marion, G. M., Farren, R. E., and Komrowski, A. J. (1999). Alternative pathways for seawater freezing. Cold Regions Science and Technology 29, 259-266. doi: 10.1016/S0165-232X(99)00033-6

Markussen, T. N., Elberling, B., Winter, C., and Andersen, T. J. (2016). Flocculated meltwater particles control Arctic land-sea fluxes. Sci. Rep. 6:24033. doi: $10.1038 /$ srep 24033

Mayer, L. M. (1982). Aggregation of colloidal iron during estuarine mixingkinetics, mechanism and seasonality. Geochim. Cosmochim. Acta 46, 1003-1009. doi: 10.1016/0016-7037(82)90055-2

Meire, L., Mortensen, J., Meire, P., Juul-Pedersen, T., Sejr, M. K., Rysgaard, S., et al. (2017). Marine-terminating glaciers sustain high productivity in Grennland fjords. Glob. Chang. Biol. 23, 5344-5357. doi: 10.1111/gcb.13801

Meire, L., Mortensen, J., Rysgaard, S., Bendtsen, J., Boone, W., Meire, P., et al. (2016). Spring bloom dynamics in a subarctic fjord influences by tidewater outlet glaciers. J. Geophys. Res. 121, 1581-1592. doi: 10.1002/2015JG003240

Meskhidze, N., Johnson, M. S., Hurley, D., and Dawson, K. (2016). Influence of measurement uncertainties on fractional solubility of iron mineral aerosols over the oceans. Aeolian Res. 22, 85-92. doi: 10.1016/j.aeolia.2016.07.002

Monien, D., Monien, P., Brunjes, R., Widmer, T., Kappenberg, A., Busso, A. A. S., et al. (2017). Meltwater as a source of potentially bioavailable iron to Antarctica waters. Antar. Sci. 29, 277-291. doi: 10.1017/S095410201600064X

Mortensen, J., Bendtsen, J., Moytka, R. J., Lennert, K., Truffer, M., Fahenstock, M., et al. (2013). On the seasonal freshwater stratification in the proximity of fast-flowing tidewater outlet glaciers in a sub-Arctic fjord. J. Geophys. Res. 118, 1382-1395. doi: 10.1002/jgrc.20134

Mortensen, J., Lennert, K., Bendtsen, J., and Rysgaard, S. (2011). Heat sources for glacial melt in a sub-arctic fjord (Godthabsfjord) in contact with the Greenland Ice Sheet. J. Geophys. Res. 116:C01013, doi: 10.1029/2010/C006528

Moses, C. O., Nordstrom, D. K., Herman, J. S., and Mills, A. L. (1987). Aqueous pyrite oxidation by dissolved oxygen and by ferric iron. Geochim. Cosmochim. Acta 51, 1561-1571. doi: 10.1016/0016-7037(87)90337-1

Nixon, S. L., Telling, J. P., Wadham, J. L., and Cockell, C. (2017). Viable coldtolerant iron-reducing microorganisms in geographically diverse subglacial environments. Biogeosciences 14, 1445-1455. doi: 10.5194/bg-14-1445-2017

Nodwell, L. M., and Price, N. M. (2001).Direct use of inorganic colloidal iron by marine thixotrophic phytoplankton. Limnol. Oceanogr. 46, 765-777. doi: 10.4319/lo.2001.46.4.0765

Nordstrom, D. K. (1982). "Aqueous pyrite oxidation and the formation of secondary iron minerals," in Acid Sulfate Weathering, eds J. A. Kittrick and D. S. Fanning (Hosner, LR: Soil Science Society of America), 37-56.

Nordstrom, D. K. (2011). Mine wastes: acidic to circumneutral. Elements 7, 393-398. doi: 10.2113/gselements.7.6.393

Poulton, S. W., and Canfield, D. E. (2005). Development of a sequential extraction procedure for iron; implications for iron partitioning in continentally derived particulates. Chem. Geol. 214, 209-221. doi: 10.1016/j.chemgeo.2004. 09.003

Raiswell, R., Benning, L. G., Davidson, L., Tranter, M., and Tulaczyk, S. (2009). Schwertmannite in wet, acid, and oxic microenvironments beneath polar and polythermal glaciers. Geology 37, 431-434. doi: 10.1130/G25350A.1

Raiswell, R., Benning, L. G., Tranter, M., and Tulaczyk, S. (2008), Bioavailable iron in the Southern Ocean: the significance of the iceberg conveyor belt. Geochem. Trans. 9:7. doi: 10.1186/1467-4866-9-7

Raiswell, R., Canfield,D. E., and Berner, R.A. (1994), A comparison of iron extraction methods for the determination of degree of pyritization and recognition of iron-limited pyrite formation. Chem. Geol. 111, 101-111. doi: 10.1016/0009-2541(94)90084-1

Raiswell, R., Hawkings, J. R., Benning, L. G., Albani, S., and Mahowald, N. (2017). Comments on 'Influence of measurement uncertainties on fractional solubility of iron mineral aerosols over the oceans. Aeolian Research 25, 123-125. doi: 10.1016/j.aeolia.2017.03.003

Raiswell, R., Hawkings, J. R., Benning, L. G., Baker, A. R., Death, R., Albani, S., et al. (2016). Potentially bioavailable iron delivery by iceberg-hosted sediments and atmospheric dust to the polar oceans. Biogeosciences 13, 1-14. doi: 10.5194/bg-13-3887-2016

Raiswell, R., Vu, H. P., Brinza, L., and Benning, L. G. (2010). The determination of $\mathrm{Fe}$ in ferrihydrite by ascorbic acid extraction: methodology, dissolution kinetics and loss of solubility with age and de-watering. Chem. Geol. 278, 70-79. doi: 10.1016/j.chemgeo.2010.09.002

Rich, H. W., and Morel, F. M. M. (1990). Availability of well-defined iron colloids to the marine diatom Thalassiosiraweissflogii. Limnol. Oceanogr. 35, 652-662. doi: 10.4319/lo.1990.35.3.0652

Rowland, G. A., and Grammas, A. M. (2011). A solid-phase chemical actinometer film for measurement of solar UV penetration into snow pack. Cold Reg. Sci. Techn. 66, 75-83. doi: 10.1016/j.coldregions.2011.01.009

Schroth, A. W., Crusius, J., Campbell, R. W., and Hoyer, I. (2014). Estuarine removal of glacial iron and implications for iron fluxes to the ocean. Geophys. Res. Lett. 41, 3951-3958. doi: 10.1002/2014GL060199

Schwertmann, U., Stanjek, H., and Becher, H.-H.,(2004). Long term in vitriol transformation of 2-line ferrihydrite to goethite/hematite at $4,10,15$ and $25^{\circ} \mathrm{C}$. Clay Miner. 39, 433-438. doi: 10.1180/0009855043940145

Shaked, Y., and Lis, H. (2012). Disassembling iron availability to phytoplankton. Front. Microbiol. 123, 1-26. doi: 10.3389/fmicb.2012.00123

Shaw, T. J., Raiswell, R., Hexel, C. R., Vu, H. P., Moore, W. S., Dudgeon, R., et al. (2011). Input, composition and potential impact of terrigenous material from free-drifting icebergs in the Weddell Sea. Deep Sea Res. II 58, 1376-1383. doi: 10.1016/j.dsr2.2010.11.012

Shi, Z., Krom, M. D., Jickells, T. J., Bonneville, S., Carlson, K. S., Mihalopoulos, N., et al. (2012). Impacts on iron solubility in the mineral dust by processes in the source region and the atmosphere: a review. Aeol. Res. 5, 21-42. doi: 10.1016/j.aeolia.2012.03.001

Shoenfelt, E. M., Sun, J., Winckler, G., Kaplan, M. R., Borunda, A. L., Farrel, K. R., et al. (2017). High particulate Fe(II) content in glacially sourced dusts enhances productivity of a model diatom. Sci. Adv. 3:e 1700314 doi: $10.1126 /$ sciadv. 1700314

Shoenfelt, E. M., Winckler, G., Lamy, F., Anderson, R. F., and Bostick, B. C. (2018). Highly bioavailable dust-borne iron delivered to the southern Ocean during glacial periods. Proc. Natl. Acad. Sci. U.S.A. 115, 11180-11185. doi: $10.1073 /$ pnas. 1809755115

Smith, K. L., Robison, B. H., Helly, J. J., Kaufmann, R. S., Ruhl, H. A., Shaw, T. J., et al. (2007). Free-drifting icebergs: Hot spots of chemical and biological enrichment in the Weddell Sea. Science 317, 478-483. doi: $10.1126 /$ science. 1142834

Smith, K. L., Sherman, A. D., Shaw, T. J., and Springall, J. (2013). Icebergs as unique Lagrangrian ecosystems in polar seas. Ann. Rev. Mar. Sci. 5, 269-287. doi: 10.1146/annurev-marine-121211-172317

Statham, P. J., Skidmore, M., and and, M., Tranter, M. (2008). Inputs of glacially derived dissolved and colloidal iron to the coastal ocean and implications for primary productivity. Glob. Biogeochem. Cycles 22:GB3013. doi: 10.1029/2007GB003106

Straneo, F., and Cenedes, C. (2015). The dynamics of Greenland's glacial fjords and their role in climate Ann. Rev. Mar. Sci. 7, 89-112. doi: 10.1146/annurev-marine-010213-135133

Stumm, W., and Morgan, J. J. (1981). Aquatic Chemistry. New York, NY: Wiley and Sons.

Tagliabue, A., Aumont, O., Death, R., Dunne, J. P., Dutkiewicz, S., Galbraith, E., et al. (2016). How well do global ocean biogeochemistry models simulate dissolved iron distributions? Global Biogeochem. Cycles 23, 17764-17774. doi: 10.1002/2015GB00528

Tagliabue, A., Bowie, A. R., Boyd, P. W., Buck, K. N., Johnson, K. S., and Sato, M. A. (2017). The integral role of iron in ocean chemistry. Nature 543, 51-59. doi: $10.1038 /$ nature21058

Telling, J., Anesio, A. M., Tranter, M., Fountain, A. G., Nylen, T., Hawkings, J., et al. (2014).Spring thaw ionic pulses boost nutrient availability and microbial growth in entombed Antarctic Dry Valley cryoconite holes. Front. Microbiol. 5:694. doi: 10.3339/fmicb.2014.0694 
Tranter, M., Huybrechts, P., Munhoven, G., Sharp, M. J., Brown, G. H., Jones, J. W., et al. (2002). Glacial bicarbonate, sulphate and base cation fluxes during the last glacial cycle, and their potential impact on atmospheric $\mathrm{CO}_{2}$. Chem. Geol. 190, 33-44. doi: 10.1016/S0009-2541(02)00 109-2

Tranter, M., and Jones, H. G. (2001). "The chemistry of snow: processes and nutrient recycling," in Snow Ecology, eds H. G. Jones, J. W. Pomeroy, D. A. Walker, and R. Hoham (Cambridge: Cambridge University Press), 127-167.

Vancoppenolle, M., Meiners, K. M., Michel, C., Bopp, L., Brabant, F., Carnat, G., et al. (2013). Role of sea ice in global biogeochemical cycles: emerging views and challenges. Quat. Sci. Rev. 79, 207-230. doi: 10.1016/j.quascirev.2013.04.011

Von der Heyden, B. P., and Roychoudhury, A. N. (2015). A review of colloidal iron partitioning and distribution in the open ocean. Mar. Chem. 177, 9-19. doi: 10.1016/j.marchem.2015.05.010

von der Heyden, B. P., Roychoudhury, A. N., Mtshall, T. N., and Tyliszcak, S. C. B. (2012). Chemically and geographically distinct solid-phase iron pools in the Southern Ocean. Science 338, 1199-1201. doi: 10.1126/science.1227504

Wadham, J. L., Tranter, M., Skidmore, M., Hodson, A. J., Priscu, J., Lyons, W. B., et al. (2010). Bigeochemical weathering under ice: size matters.Glob. Biogeochem. Cycles 24:GB3025. doi: 10.1029/2009GB003688

Wang, S., Bailey,D., Lindsay, K., Moore, J. K., and Holland, M. (2014), Impact of sea ice on the marine iron cycle and phytoplankton productivity. Biogeosciences 11, 4713-4731. doi: 10.5194/bg-11-4713-2014

Waychunas, G. A., Kim, C. S., and Banfield, J. F. (2005). Nanoparticulate iron oxide minerals in soils and sediments: unique properties and contaminant scavenging mechanisms. J. Nanopart. Res. 7, 409-433. doi: 10.1007/s11051-0056931-x

Wehrmann, L. M., Formolo, M. J., Owens, J. D., Raiswell, R., Ferdelman, T. G., Riedinger, N., et al. (2014). Iron and manganese speciation and cycling in glacially-influenced high-latitude fjord sediments (West Spitzbergen, Svalbard): evidence for a benthic recycling-transport mechanism. Geochim. Cosmochim. Acta 141, 628-655. doi: 10.1016/j.gca.2014. 06.007

Wells, M. J., and Goldberg, E. D. (1994). Marine sub-micron particles. Mar. Chem. 40 5-18. doi: 10.1016/0304-4203(92)90045-C

Wells, M. L., Zorkin, N. G., and Lewis, A. G. (1983). The role of colloid chemistry in providing a source of iron to phytoplankton. J. Mar. Res. 41, 731-746. doi: $10.1357 / 002224083788520478$

Winton, V. H. L., Bowie, A. R., Edwards, R., Keywood, M., Townsend, A. T., van der Merwe, P., et al. (2015). Fractional solubility of atmospheric iron inputs to the Southern Ocean. Mar. Chem. 177, 20-32. doi: 10.1016/j.marchem.2015.06.006

Yoshida, M., Kuma, K., Iwade, S., Isoda, Y., Takata, H., and Yamada, M. (2006). Effect of aging time on the availability of freshly precipitated ferric hydroxide to coastal marine diatoms. Mar. Biol. 149, 379-392. doi: 10.1007/s00227-005-0187-y

Zhang, R., John, S. G., Zhang, J., Ren, J., Wu, Y., Zhu, Z., et al. (2015). Transport and reaction of iron and iron stable isotopes in glacial meltwaters on Svalbard near Kongsfjorden: From rivers to estuary to ocean. Earth Planet. Sci. Lett. 424, 201-211. doi: 10.1016/j.epsl.2015.05.031

Conflict of Interest Statement: The authors declare that the research was conducted in the absence of any commercial or financial relationships that could be construed as a potential conflict of interest.

Copyright (c) 2018 Raiswell, Hawkings, Elsenousy, Death, Tranter and Wadham. This is an open-access article distributed under the terms of the Creative Commons Attribution License (CC BY). The use, distribution or reproduction in other forums is permitted, provided the original author(s) and the copyright owner(s) are credited and that the original publication in this journal is cited, in accordance with accepted academic practice. No use, distribution or reproduction is permitted which does not comply with these terms. 